\title{
Barite Precipitation on Suspended Organic Matter in the Mesopelagic Zone
}

\author{
F. Martinez-Ruiz ${ }^{1 *}$, A. Paytan ${ }^{2}$, M. T. Gonzalez-Muñoz ${ }^{3}$, F. Jroundi ${ }^{3}$, M. M. Abad ${ }^{4}$, P. J. Lam ${ }^{2}$, \\ T. J. Horner ${ }^{5}$ and M. Kastner ${ }^{6}$ \\ ${ }^{1}$ Instituto Andaluz de Ciencias de la Tierra (CSIC-UGR), Avda. de las Palmeras, Granada, Spain, ${ }^{2}$ Institute of Marine Sciences, \\ University of California Santa Cruz, Santa Cruz, CA, United States, ${ }^{3}$ Department of Microbiology, Faculty of Science, University of \\ Granada, Campus Fuentenueva, Granada, Spain, ${ }^{4}$ Centro de Instrumentación Cientifica (CIC), University of Granada, Campus \\ Fuentenueva, Granada, Spain, ${ }^{5}$ Department of Marine Chemistry and Geochemistry, Woods Hole Oceanographic Institution, \\ Woods Hole, MA, United States, 'SCripps Institution of Oceanography, University of California, San Diego, La Jolla, CA, United \\ States
}

OPEN ACCESS

Edited by:

Rut Pedrosa Pàmies,

Marine Biological Laboratory (MBL), United States

Reviewed by: Frank Dehairs, Vrije University Brussel, Belgium

Christophe Monnin,

Géosciences Environnement

Toulouse (GET), France

${ }^{*}$ Correspondence:

F. Martinez-Ruiz fmruiz@ugr.es

Specialty section: This article was submitted to Biogeoscience,

a section of the journal

Frontiers in Earth Science

Received: 30 May 2020 Accepted: 05 October 2020 Published: 28 October 2020

Citation: Martinez-Ruiz F, Paytan A, GonzalezMuñoz MT, Jroundi F, Abad MM, Lam $P J$, Horner TJ and Kastner M (2020) Barite Precipitation on Suspended Organic Matter in the Mesopelagic Zone.

Front. Earth Sci. 8:567714. doi: 10.3389/feart.2020.567714
Mechanisms underlying barite precipitation in seawater and the precise depths of barite precipitation in the water column have been debated for decades. Here we present a detailed study of water column barite distribution in the mesopelagic zone at diverse stations in the open ocean by analyzing samples collected using multiple unit large volume in-situ filtration systems in the Pacific, Atlantic and Indian oceans. Our results demonstrate that barite is an organo-mineral particularly abundant at intermediate depths throughout the world's ocean regardless of saturation state with respect to barite. This is confirming the notion of precipitation at depths of intense organic matter mineralization. Our observations further support the link between barite formation and microbial activity, demonstrated by the association of barite particles with organic matter aggregates and with extracellular polymeric substances. Evidence for microbial mediation is consistent with previous experimental work showing that in bacterial biofilms Ba binds to phosphate groups on cell surfaces and within extracellular polymeric substances. This organoaccumulation promotes high concentrations of $\mathrm{Ba}$ leading to saturated microenvironments and nucleation sites favoring precipitation. The distribution of $\mathrm{Ba}$ isotopes in the water column and in particulate matter is also consistent with the proposed precipitation mechanism.

Keywords: pelagic barite, organo-mineralization, barite saturation state, extracellular polymeric substances, bioaccumulation

\section{INTRODUCTION}

Barium and barite are routinely used for reconstructing past export production in the ocean yet the processes linking barite formation to export production are still elusive. Since the early work of Chow and Goldberg (1960) who reported high Ba concentrations in marine sediments underlying regions of high biological productivity, a link between organic matter fluxes and $\mathrm{Ba}$ abundance has been broadly demonstrated (e.g., Dehairs et al., 1980; Dymond et al., 1992; Francois et al., 1995; Paytan et al., 1996; Paytan and Griffith 2007; Griffith and Paytan, 2012; Carter et al., 2020 and references therein). Studies using sediment traps have provided further evidence on the association of particulate $\mathrm{Ba}$ and particulate organic carbon (POC). It has been proposed that barite 
precipitates in close association with aggregates of organic matter and sinking biological debris (e.g., Bishop, 1988; Dehairs et al., 1991). Different algorithms have been suggested to correlate export production and excess $\mathrm{Ba}$ (total $\mathrm{Ba}$ concentration corrected for the lithogenic phase) or barite accumulation (e.g., Dymond et al., 1992; Francois et al., 1995; Paytan et al., 1996; Eagle et al., 2003), allowing the reconstruction of past ocean productivity (e.g., Dymond et al., 1992; Gingele and Dahmke, 1994; Nürnberg et al., 1997; Eagle et al., 2003; Ma et al., 2015). Nevertheless, quantification of export production from $\mathrm{Ba}$ proxies is still hindered by poor understanding of the mechanisms and processes leading to barite (the main phase carrying excess $\mathrm{Ba}$ ) formation in the oceanic water column. Moreover, barite distribution in the oceanic water column is variable in space, time, and depth and such variability is not yet fully understood (e.g., Hernandez-Sanchez et al., 2011; Bates et al., 2017).

Over decades of research, several hypotheses have been proposed to explain barite precipitation in the oceanic water column given that most of the world's ocean mesopelagic zone (200-1,000 m depth, Sutton et al., 2017) is undersaturated with respect to barite (Monnin et al., 1999; Rushdi et al., 2000). Hypotheses included precipitation in microenvironments formed within sinking biogenic particulate matter (e.g., Dehairs et al., 1980; Bishop, 1988), precipitation as a result of celestine $\left(\mathrm{SrSO}_{4}\right)$ dissolution from Acantharian tests (e.g., Bernstein et al., 1992; Bernstein et al., 1998) and by way of microbially mediated precipitation processes (Gonzalez-Muñoz et al., 2003; Gonzalez-Muñoz et al., 2012; Torres-Crespo et al., 2015). Specifically, Gonzalez-Muñoz et al. (2003) demonstrated in laboratory culture experiments the ability of soil bacteria to induce precipitation of barite, and later also highlighted the potential role of bacteria in barite precipitation in the ocean by using diverse marine strains in culture experiments (GonzalezMuñoz et al., 2012; Torres-Crespo et al., 2015). Bacterially mediated precipitation of barite is consistent with studies demonstrating the positive correlation between mesopelagic particulate $\mathrm{Ba}$ abundance and enhanced bacterial production in the North Pacific and the Southern Ocean as well as the relation between particulate $\mathrm{Ba}$ abundance and microbial oxygen consumption (Dehairs et al., 2008; Jacquet et al., 2011; Planchon et al., 2013). Moreover, mesocosm experiments inducing the decay of various phytoplankton species in the dark demonstrated that $\mathrm{Ba}$ is released during the decomposition of the phytoplankton, leading to barite precipitation (Ganeshram et al., 2003). Overall, several lines of evidence have supported the suggestion that the nutrient-like behavior of $\mathrm{Ba}$ is due to biological processes mediating barite precipitation. In particular, analyses of $\mathrm{Ba}$ isotopes of both water column and particulate matter at various sites in the ocean (e.g., Horner et al., 2015; Bates et al., 2017; Bridgestock et al., 2018) are also consistent with the formation of barite which preferentially incorporates the light $\mathrm{Ba}$ isotope at mesopelagic depths.

Additional experimental work (Martinez-Ruiz et al., 2018) demonstrated that bacterial biofilms, specifically, extracellular polymeric substances (EPS) may play a major role in barite precipitation by providing nucleation sites to locally enhance
$\mathrm{Ba}$ concentration leading to barite precipitation. This work also showed that an amorphous P-rich phase is formed at the initial stages of Ba bioaccumulation eventually being replaced by sulfate and leading to the formation of barite crystals. The capacity of EPS to bind metal ions to negatively charged functional groups has been broadly demonstrated (e.g., Braissant et al., 2007; Tourney and Ngwenya, 2014) and the role of phospholipids acting as nucleation sites to incorporate diverse cations has been demonstrated for diverse metals such as $U$ (e.g., Morcillo et al., 2014). Moreover, P-rich precursors have been described in the precipitation of several minerals such as aragonite apatite and iron oxides, both under experimental conditions (Rivadeneyra et al., 2010), and in the geological record (e.g., Sanchez-Navas and Martin-Algarra, 2001; Miot et al., 2009). In general, microbial precipitation through an amorphous precursor is a widespread process in natural environments (e.g., Weiner et al., 2005; Enyedi et al., 2020). Such crystallization path through an amorphous precursor phase is also associated with the inorganic precipitation of barite. For example, a metastable amorphous Ba sulfate phase that precedes barite formation has been recognized during the early stages of barium sulfate crystallization from aqueous solutions (Ruiz-Agudo et al., 2020), however, the binding of Ba to EPS in the open ocean has not been thoroughly investigated.

Mineralogical and crystallographic analyses of marine barite collected using multiple unit large volume in-situ filtration systems (MUL-VFS) at two stations in the North Atlantic and the Atlantic sector of the Southern Ocean demonstrated that barite formation in the open ocean also involves an amorphous precursor (Martinez-Ruiz et al., 2019). This initial amorphous precursor is a phosphorus-rich phase that evolves into barite when phosphate groups are substituted by sulfate. These crystallization pathways are similar to those reported to form within biofilms in laboratory based experiments (Martinez-Ruiz et al., 2018). These findings support the role of EPS in the precipitation of barite in the oceanic water column and the correlation between bacterial production and the abundance of Ba-rich particles. As our previous study (Martinez-Ruiz et al., 2019) focused only on two stations, from the North Atlantic and the Atlantic Sector of the Southern Ocean, the present work aims at providing new insights into the mechanisms of barite formation in the ocean water column by analyzing barite, also collected by MUL-VFS, at new stations representing additional ocean sectors with diverse barite saturation conditions. Stations within each sector were selected in high productivity settings. Barite crystallography, mineralogy and abundance in the water column have been investigated at different depths within the mesopelagic zone at the locations and sites described below.

\section{SAMPLES AND METHODS}

\section{Oceanographic Setting}

Locations for this study have been selected to represent four different ocean sectors (Figure 1; Table 1) where productivity is relatively high and hence barite is abundant in the upper water column however these sites represent different saturation states within the mesopelagic zone. 


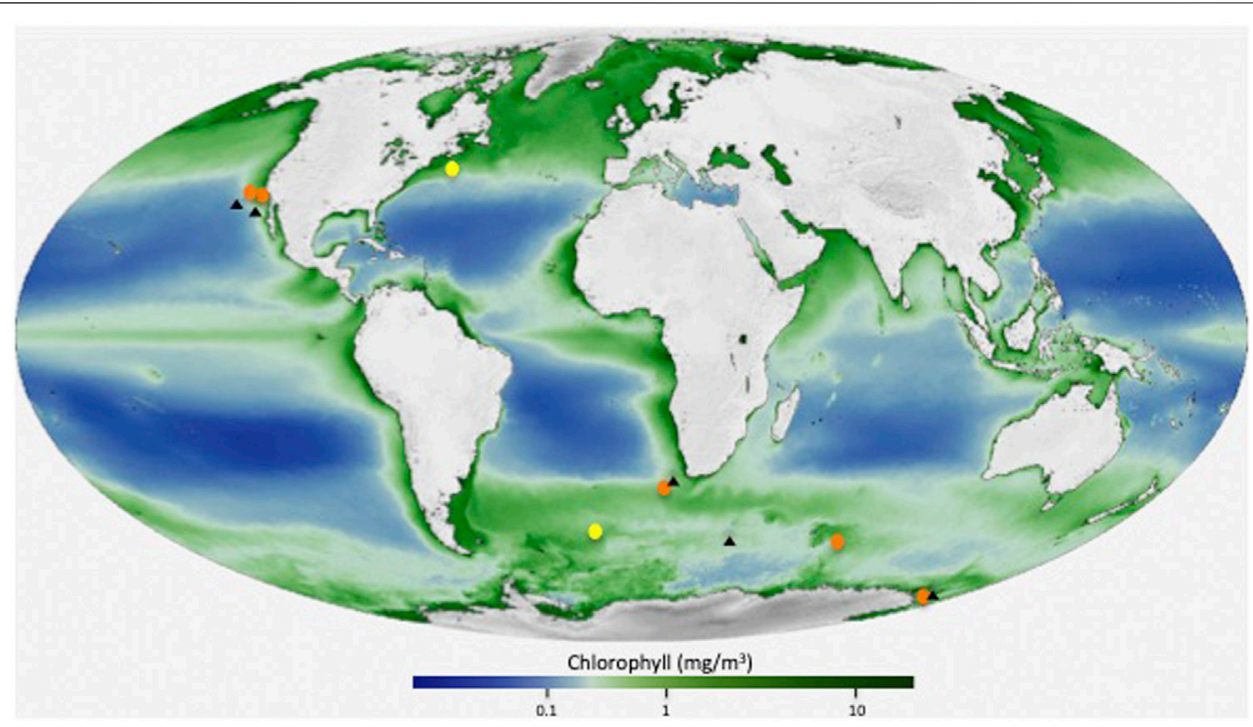

FIGURE 1 | Location map showing the analyzed stations (orange color), and two previously analyzed sites (yellow color) in the North Atlantic and in the Atlantic sector of the Southern Ocean (Martinez-Ruiz et al., 2019). Black triangles indicate the location of the stations with available Ba concentration depth profiles used for $\Omega_{\text {barite }}$ calculations. Base map modified from NASA/Goddard Space Flight Center, The SeaWiFS Project and GeoEye maps, https://svs.gsfc.nasa.gov/30801).

North Pacific: OC1608A, C-SNOW cruise, California current system, coastal North Pacific Station 1 (1,929 m water depth), and OC1608A, C-SNOW cruise, California current system, Santa Barbara basin, Station 2 (4,880 $\mathrm{m}$ water depth). These stations are at the edge of the North Pacific oligotrophic gyre. The North Pacific Subtropical Gyre harbors one of the largest biomas on Earth, it is a relatively stable oligotrophic environment, with low surface concentrations of nitrogen and phosphorus. Nutrients derived from advective transport from depth into the surface ocean stimulates primary production in this region (Karl and Church, 2017; Robidart et al., 2019). The two stations in the Santa Barbara basin are on the edge of this gyre and are characterized by relatively high productivity and high phytoplankton biomass that supports a productive pelagic ecosystem (Letelier, et al., 2019). The productivity is fueled by intensive coastal upwelling induced by northerly winds along the California margin (e.g., Brzezinski and Washburn, 2011; Abella-Gutiérrez and Herguera, 2016).

Atlantic: MV1101, Great Calcite Belt (GCB) 1, South Atlantic, Station 117 (Rosengard et al., 2015; Balch et al., 2016). During the GCB1 cruise the R/V Melville crossed the Atlantic sector from Punta Arenas, Chile, to Cape Town, South Africa, sampling between $39^{\circ} \mathrm{S}$ and $59^{\circ} \mathrm{S}$. Station 92 from this cruise has been previously analyzed for marine barite (Martinez-Ruiz et al., 2018) and station 117 has been selected for this study $(5,048 \mathrm{~m}$ water depth). Station GCB1-117 is located in the subtropical region of the South Atlantic Ocean and is dominated by seasonal coccolithophores and diatoms blooms (Smith et al., 2017).

Indian ocean: RR1202, Great Calcite Belt (GCB) 2, South Indian Ocean, Station 63 (Rosengard et al., 2015; Balch et al., 2016; Smith et al., 2017). During the GCB2 cruise, the R/V Revelle crossed the Indian sector from Durban, South Africa, to Perth, Australia, sampling between $37^{\circ} \mathrm{S}$ and $60^{\circ} \mathrm{S}$. Station 63 has been selected for this study (1,310 $\mathrm{m}$ water depth). The region is characterized by elevated surface reflectance that is thought to result from high seasonal concentrations of coccolithophores. Data for multiple parameters sampled during the GCB cruises including chlorophyll, particulate inorganic carbon (PIC), POC, biogenic silica (BSi), coccolithophore concentration, calcification, photosynthesis, dissolved inorganic carbon (DIC), total alkalinity, iron limitation of phytoplankton and ${ }^{234} \mathrm{Th}$ based vertical flux rates are available for these stations (Rosengard et al., 2015; Balch et al., 2016). Shipboard scientists reported dense coccolithophore populations that exported small, highly degraded, and compact particles out of the euphotic zone. Coccolithophore blooms are considered very efficient in transferring POC to the base of the mesopelagic zone, although the magnitude of exported POC is not as high as in diatom-rich regions (e.g., Henson et al., 2012).

South Pacific: NBP1101, Seafarers cruise, Ross Sea, Station 14. This station is located off the Ross Sea Shelf in the Pacific $(1,887 \mathrm{~m})$. Samples were collected between January 17 , and February 13, 2011 aboard the R/V Nathaniel B (Hatta et al., 2017). The Ross Sea continental shelf is one of the most productive areas in the Southern Ocean (e.g., Smith, Jr. et al., 2014). Here a significant supply of dissolved Fe to surface waters is required to sustain high productivity (Sedwick et al., 2011; Hatta et al., 2017), and include dust, sea-ice, icebergs and upwelling of deeper waters as some of the main inputs (e.g., Measures et al., 2012; Marsay et al., 2014).

\section{Particulate Ba Sampling, Particulate Organic Carbon Analyses, and Barite Saturation State $\left(\Omega_{\text {barite }}\right)$}

Size-fractionated particulate material has been collected using multiple MUL-VFS (Bishop et al., 1985) and battery-operated McLane in-situ pumps (LV-WTS) (Rosengard et al., 2015). Analyzed samples and corresponding depths are indicated in Table 1. Particulate $\mathrm{Ba}$ concentrations (pBa) have been 
TABLE 1 | Analyzed samples for this study.

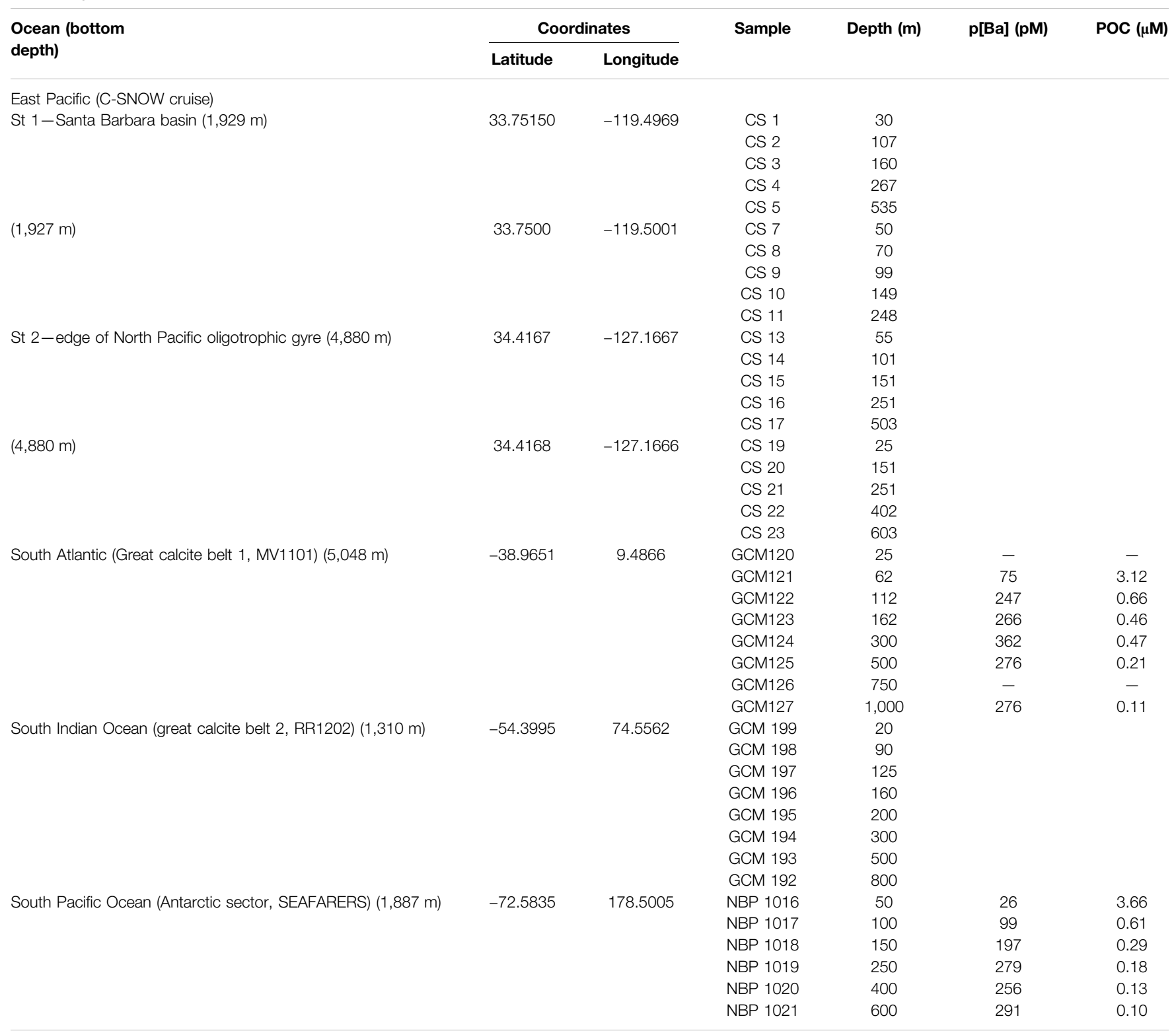

determined at the South Atlantic (Great Calcite Belt) and South Pacific Ocean (Antarctic sector) stations, but these data are not available at other stations. In situ deployed filters were processed using the protocol described in Bishop and Wood (2008). Samples for $\mathrm{pBa}$ were collected on PES filters to ensure low blank and $\mathrm{Ba}$ concentrations in the particulate leachate was analyzed using an iCAP RQ inductively-coupled plasma mass spectrometer. Quantification was achieved via comparison of blank- and indium-normalized ion beam intensities in samples against those measured in a serially diluted multi-element standard that was prepared in house. Precision is generally better than $\pm 3 \%$ relative standard deviation. POC samples were collected on precombusted QMA filters and concentrations were measured using a CHN elemental analyzer immediately on the ship during the cruises as described in Rosengard et al. (2015). Sampling details and complication associated with particles collected by MUL-VFS as well as retention efficiency are discussed in detail in Bishop et al. (2012). In the South Indian ocean station, both large $(>51 \mu \mathrm{m})$ and small $(1-51 \mu \mathrm{m})$ size particulates were analyzed. For the rest of stations, only filters retaining the $1-51 \mu \mathrm{m}$ fraction were analyzed. The MUL-VFS sampling was found to be highly suitable for barite particles retention and QMA filters were ideal for barite microscopic detection and observation.

To place the $\mathrm{p}[\mathrm{Ba}]$ data in context, we calculated the barite saturation state of seawater with respect to barite $\left(\Omega_{\text {barite }}\right)$ at the depths of sample collection $\Omega_{\text {barite }}$ is the ratio between the barium and sulfate ion activity product and the barite solubility product. Values of $\Omega<1,=1$, and $>1$ indicate under-, perfect-, and super-saturation, respectively. For consistency with the literature, we consider water samples with $\Omega$ between 0.9 and 1.1 as being in saturation equilibrium (e.g., Monnin et al., 1999). Since co-located 
TABLE 2 | Dissolved Ba, temperature, and calculated profiles of dissolved $\Omega_{\text {barite }}$ across depth in nearby stations to those analyzed in this work (co-located dissolved samples were generally not available for our study).

\section{East Pacific (close to C-SNOW St. 1)}

\begin{tabular}{|c|c|c|c|}
\hline Cruise & \multicolumn{3}{|c|}{ GEOSECS Test } \\
\hline Station & \multicolumn{3}{|c|}{ Test } \\
\hline Location & \multicolumn{3}{|c|}{$28.483^{\circ} \mathrm{N}, 121.633^{\circ} \mathrm{W}$} \\
\hline Collected & \multicolumn{3}{|c|}{ September 1969} \\
\hline Citation & \multicolumn{2}{|c|}{ Wolgemuth and Broecker, 1970} & \\
\hline Depth (m) & [Ba] (nM) & Temperature $\left({ }^{\circ} \mathrm{C}\right)$ & $\Omega_{\text {barite }}$ \\
\hline 1 & 50 & 18.07 & 0.29 \\
\hline 30 & 43 & 17.85 & 0.25 \\
\hline 150 & 50 & 11.66 & 0.39 \\
\hline 255 & 57 & 8.71 & 0.50 \\
\hline 400 & 67 & 6.9 & 0.65 \\
\hline 700 & 85 & 5.07 & 0.89 \\
\hline 1,000 & 93 & 4.01 & 1.02 \\
\hline
\end{tabular}

Northeast Pacific (close to C-SNOW St. 2)

\begin{tabular}{|c|c|c|c|}
\hline \multirow{5}{*}{$\begin{array}{l}\text { Cruise } \\
\text { Station } \\
\text { Location } \\
\text { Collected } \\
\text { Citation }\end{array}$} & \multicolumn{3}{|l|}{ KN195-08 } \\
\hline & \multicolumn{3}{|c|}{ SAFe } \\
\hline & \multicolumn{3}{|c|}{$30^{\circ} \mathrm{N}, 140^{\circ} \mathrm{W}$} \\
\hline & \multicolumn{3}{|c|}{ May 2009} \\
\hline & \multicolumn{3}{|c|}{$\begin{array}{l}\text { Geyman et al., } 2019 \\
\text { doi:10.1016/j.epsl.2019.115751 }\end{array}$} \\
\hline Depth (m) & [Ba] (nM) & Temperature $\left({ }^{\circ} \mathrm{C}\right)$ & $\Omega_{\text {barite }}$ \\
\hline 25 & 35.0 & 19.01 & 0.20 \\
\hline 75 & 37.8 & 18.20 & 0.22 \\
\hline 110 & 35.0 & 18.18 & 0.20 \\
\hline 150 & 35.3 & 16.76 & 0.22 \\
\hline 200 & 37.1 & 12.81 & 0.27 \\
\hline 250 & 37.5 & 11.23 & 0.30 \\
\hline 300 & 39.4 & 9.92 & 0.33 \\
\hline 350 & 43.5 & 8.85 & 0.38 \\
\hline 400 & 48.9 & 7.95 & 0.45 \\
\hline 500 & 59.4 & 6.32 & 0.59 \\
\hline 600 & 68.3 & 5.19 & 0.71 \\
\hline 700 & 77.9 & 4.64 & 0.83 \\
\hline 850 & 89.4 & 4.08 & 0.98 \\
\hline 1.000 & 98.1 & 3.72 & 1.10 \\
\hline
\end{tabular}

\section{South Atlantic (close to MV1101 St. 117)}

\begin{tabular}{|c|c|c|c|}
\hline Cruise & D357 (GA1 & & \\
\hline Station & 3 & & \\
\hline Location & $36^{\circ} 27.6^{\prime} \mathrm{S}$ & & \\
\hline Collected & October 20 & & \\
\hline Citation & $\begin{array}{l}\text { Bates et al. } \\
\text { doi: } 10.1016\end{array}$ & 17.01 .043 & \\
\hline Depth (m) & [Ba] (nM) & Temperature $\left({ }^{\circ} \mathrm{C}\right)$ & $\Omega_{\text {barite }}$ \\
\hline 5 & 43.0 & 12.08 & 0.32 \\
\hline 23 & 42.4 & 12.07 & 0.32 \\
\hline 47 & 42.6 & 12.06 & 0.32 \\
\hline 97 & 44.5 & 11.19 & 0.36 \\
\hline 196 & 43.3 & 10.8 & 0.34 \\
\hline 395 & 48.0 & 8.17 & 0.44 \\
\hline 594 & 56.1 & 5.22 & 0.59 \\
\hline 989 & 70.6 & 3.64 & 0.79 \\
\hline
\end{tabular}

TABLE 2 | (Continued) Dissolved Ba, temperature, and calculated profiles of dissolved $\Omega_{\text {barite }}$ across depth in nearby stations to those analyzed in this work (co-located dissolved samples were generally not available for our study).

\begin{tabular}{|c|c|c|c|}
\hline \multicolumn{4}{|c|}{ South Indian Ocean (close to RR1202 St. 63) } \\
\hline Cruise & \multicolumn{3}{|c|}{ INDIGO 1} \\
\hline Station & \multicolumn{3}{|c|}{18} \\
\hline Location & \multicolumn{3}{|c|}{$45^{\circ} 09^{\prime} \mathrm{S}, 72^{\circ} 20^{\prime} \mathrm{E}$} \\
\hline Collected & \multicolumn{3}{|c|}{ March 1985} \\
\hline Citation & \multicolumn{3}{|c|}{$\begin{array}{l}\text { Jeandel et al., } 1996 \\
\text { doi:10.1016/0967-0637(95)00098-4 }\end{array}$} \\
\hline Depth (m) & $\mathrm{d}[\mathrm{Ba}]$ & Temperature $\left({ }^{\circ} \mathrm{C}\right)$ & $\Omega_{\text {barite }}$ \\
\hline 99 & 52.7 & 8.84 & 0.47 \\
\hline 124 & 53.3 & 7.78 & 0.49 \\
\hline 152 & 54.1 & 7.24 & 0.51 \\
\hline 197 & 55.9 & 6.32 & 0.55 \\
\hline 295 & 54.9 & 6.12 & 0.55 \\
\hline 397 & 58.5 & 5.00 & 0.62 \\
\hline 792 & 65.8 & 3.07 & 0.76 \\
\hline 1,039 & 68.6 & 2.58 & 0.81 \\
\hline
\end{tabular}

South Indian Ocean (close to RR1202 St. 63)

$\begin{array}{ll}\text { Cruise } & \text { INDIGO } 3 \\ \text { Station } & 90 \\ \text { Location } & 55^{\circ} 01^{\prime} \mathrm{S}, 31^{\circ} 13^{\prime} \mathrm{E} \\ \text { Collected } & \text { June } 1987 \\ \text { Citation } & \text { Jeandel et al., } 1996 \\ & \text { doi:10.1016/0967-0637(95)00098-4 }\end{array}$

\begin{tabular}{lccc}
\hline Depth $(\mathbf{m})$ & $\mathbf{d}[\mathrm{Ba}]$ & Temperature $\left({ }^{\circ} \mathbf{C}\right)$ & $\boldsymbol{\Omega}_{\text {barite }}$ \\
\hline 52 & 76.6 & 2.06 & 0.93 \\
76 & 76.1 & 1.44 & 0.96 \\
100 & 77.7 & 1.22 & 0.98 \\
151 & 77.6 & 0.95 & 0.98 \\
198 & 77.6 & 1.10 & 0.98 \\
303 & 80.8 & 1.91 & 0.98 \\
400 & 82.2 & 1.70 & 1.00 \\
496 & 81.6 & 1.93 & 1.00 \\
745 & 88.1 & 1.82 & 1.12 \\
891 & 87.2 & 1.79 & 1.07 \\
1,289 & 91.0 & 1.45 & 1.15 \\
\hline
\end{tabular}

Southern Ocean (close to NBP1101 St. 14)

\begin{tabular}{ll} 
Cruise & GEOSECS \\
Station & 287 \\
Location & $-69.3^{\circ} \mathrm{S}, 186.5^{\circ} \mathrm{E}$ \\
Collected & February 1974 \\
Citation & $\begin{array}{l}\text { Ku et al., } 1976 \\
\text { doi:10.1016/0012-821X(76) } 90064-9\end{array}$ \\
\hline
\end{tabular}

\begin{tabular}{lccc}
\hline Depth $(\mathbf{m})$ & $\mathbf{d}[\mathbf{B a}]$ & Temperature $\left({ }^{\circ} \mathbf{C}\right)$ & $\boldsymbol{\Omega}_{\text {barite }}$ \\
\hline 2 & 77.8 & -1.07 & 1.10 \\
21 & 77 & -1.49 & 1.02 \\
41 & 78.2 & -1.40 & 1.12 \\
81 & 78.1 & -1.65 & 1.12 \\
151 & 79.8 & -0.31 & 1.07 \\
201 & 83.1 & 0.87 & 1.07 \\
272 & 84.7 & 1.43 & 1.05 \\
352 & 85.7 & 1.43 & 1.07 \\
449 & 92.6 & 1.37 & 1.15 \\
598 & 89.8 & 1.27 & 1.12 \\
797 & 92 & 1.12 & 1.18 \\
996 & 94.5 & 0.97 & 1.20
\end{tabular}



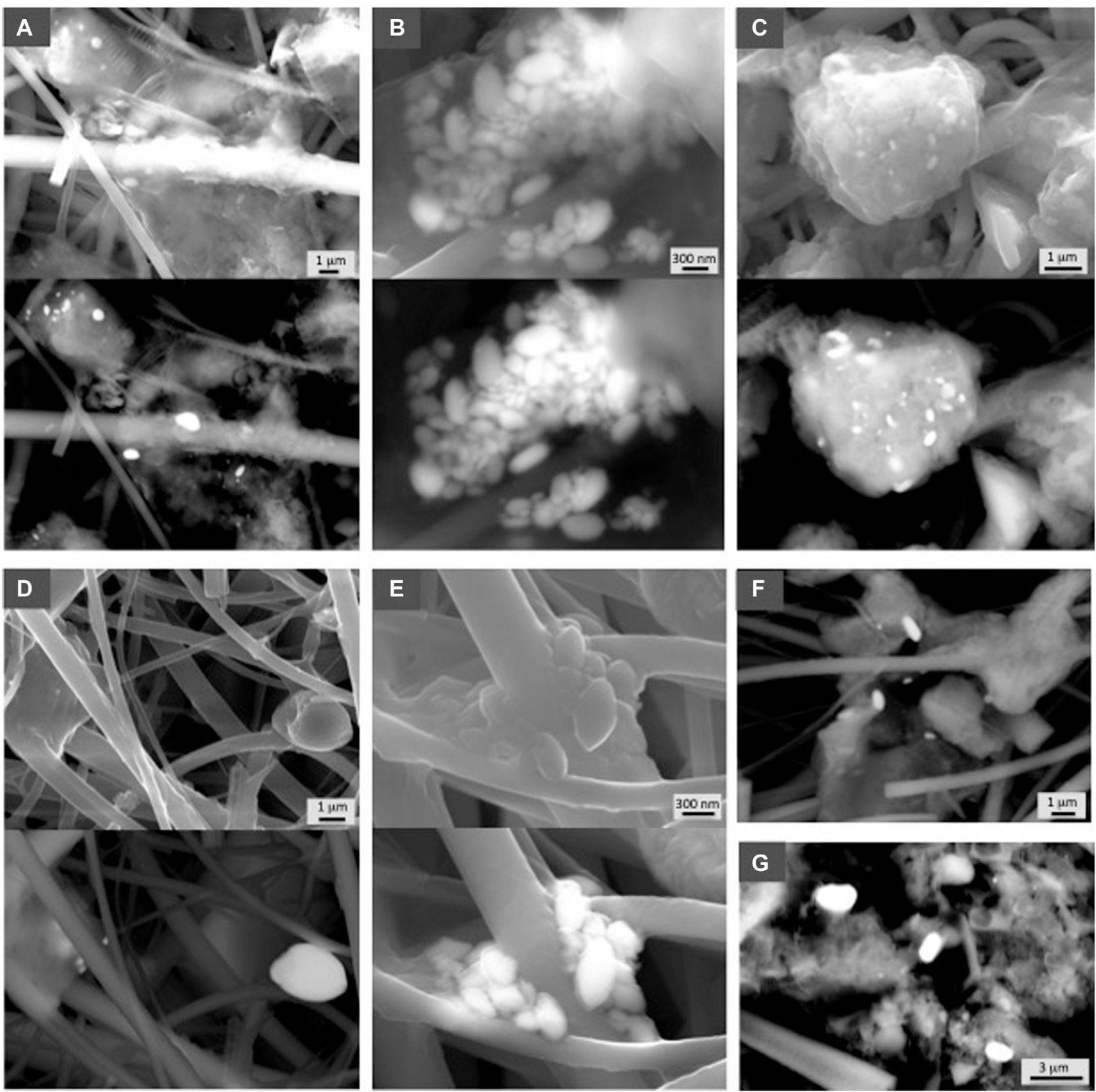

FIGURE 2 | SEM photographs showing representative examples of barite from the Pacific sector. Samples are indicated in Table 1. Both secondary electron and in backscattered electron (BSE) mode at $30 \mathrm{kV}$ are shown in each sample. (A) CS4 (267 m), (B) CS9 (99 m), (C) CS10 (149 m), (D) CS20 (151 m), (E) CS 17 (503 m). (F) (CS 23) and (G) (CS 5) correspond to the deepest filter samples obtained at this ocean sector, 603 and $535 \mathrm{~m}$, respectively.

samples for analysis of dissolved Ba and sulfate were generally not available for our study, we estimated $\Omega_{\text {barite }}$ from nearby stations with reliable published Ba concentration depth profiles (see Table 2 for details and Figure 1 for locations). Calculations were performed using PHREEQC version 3 (Parkhurst and Appelo, 2013). Values of $\Omega_{\text {barite }}$ were computed for each sample based on input parameters of in situ temperature, $\mathrm{d}$ [Ba], pressure (estimated from depth). Both $\mathrm{pH}$ and salinity were prescribed in all calculations at 8.1 and 35 , respectively. The major ion composition of seawater in the calculations was based on that reported by Kester et al. (1967). We believe that using a fixed salinity in our calculations is a reasonable assumption given the relatively minor effect this property has on $\Omega_{\text {barite }}$ over the range of salinities encountered in open ocean seawater.

\section{Electron Microscopy Observations}

Quartz fiber filters (Whatman QMA) have been used for scanning electron microscopy (SEM) observation and analyses. Representative filter pieces were coated with 

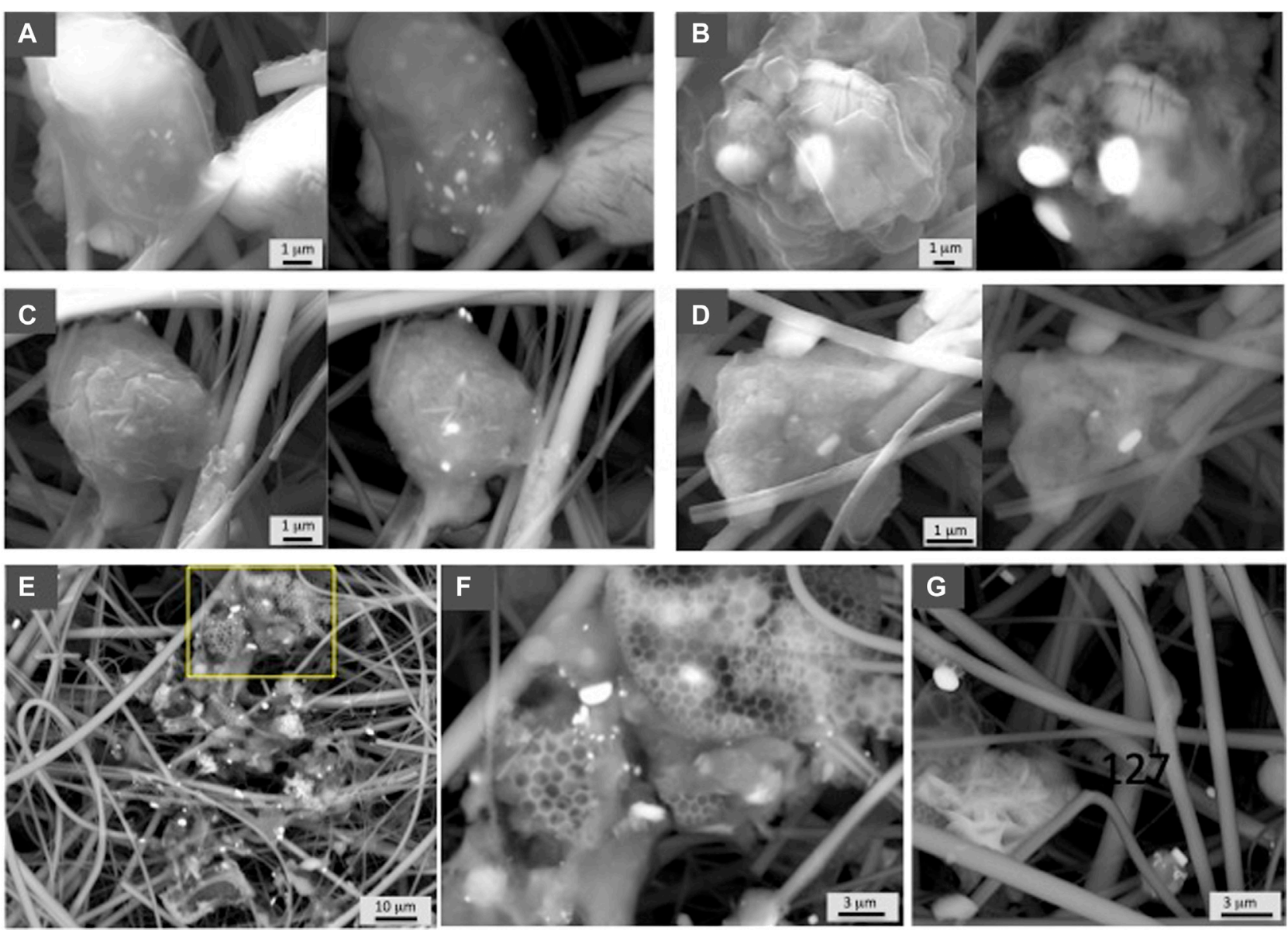

FIGURE 3 | SEM photographs showing representative examples of barite from the Atlantic sector analyzed in this study. Samples are indicated in Table 1. Both secondary electron and in backscattered electron (BSE) mode at 30 kV are shown in each sample. (A) GCM 122 (112 m), (B) GCM 123 (162 m), (C) GCM 124 (300 m), and (D) GCM 126 (750 m). (E) GCM $125(500 \mathrm{~m})$ shows the barite abundance at $500 \mathrm{~m}$ depth, and (F) GCM 127 (1,000 m) shows a detailed image of the square indicated in photograph e, in which different sizes of barite grains are shown in organic aggregates. (G) GCM 127 corresponds to the deepest filter sample obtained at this ocean sector, $1,000 \mathrm{~m}$, in which barite is not abundant but still present.

carbon for observation under the SEM using an AURIGA FIBFESEM Carl Zeiss SMT microscope equipped with an energy dispersive X-ray (EDX) detector system (Centre for Scientific Instrumentation, University of Granada). Filter pieces were grounded in an agate mortar and then dispersed in ethanol by sonication for approximately $3 \mathrm{~min}$. Particulate matter released from the filter was deposited on carbon-film-coated copper grids for high-resolution transmission electron microscopy (HRTEM) observation by using a FEI TITAN G2 60-300 microscope with a high brightness electron gun (X-FEG) operated at $300 \mathrm{kV}$ and equipped with a Cs image corrector CEOS (Centre for Scientific Instrumentation, University of Granada). For analytical electron microscopy (AEM), a SUPER-X silicon-drift windowless EDX detector was used. EDX maps and selected area electron diffraction (SAED) patterns were also collected on barite particles for crystallographic characterization and for determining major constituents composition.

\section{RESULTS}

Barite particles were observed in all the analyzed samples from all the locations and water depths (Figures 2-6). Figure 2 shows representative examples of barite particles from the Coastal East Pacific water column. Barite shows typical rounded to oval morphologies ranging in size from nanometers to a few microns, and it is always associated with organic material, which in many cases has EPS-like morphology (Figures 2A,C,E). Aggregates of barite grains are commonly observed with grains of different sizes ranging from less than $100 \mathrm{~nm}$ to a few hundred nm (Figure 2B). Barite is also observed as individual barite grains of micron size (Figure 2D) present at all depth analyzed. Figures 2F,G show examples of the deepest samples analyzed at 603 and $535 \mathrm{~m}$ water depth at these stations.

Figure 3 shows examples from the South Atlantic sector demonstrating barite associated with organic aggregates, which in some cases show EPS-like morphologies (Figure 2D). SEM 

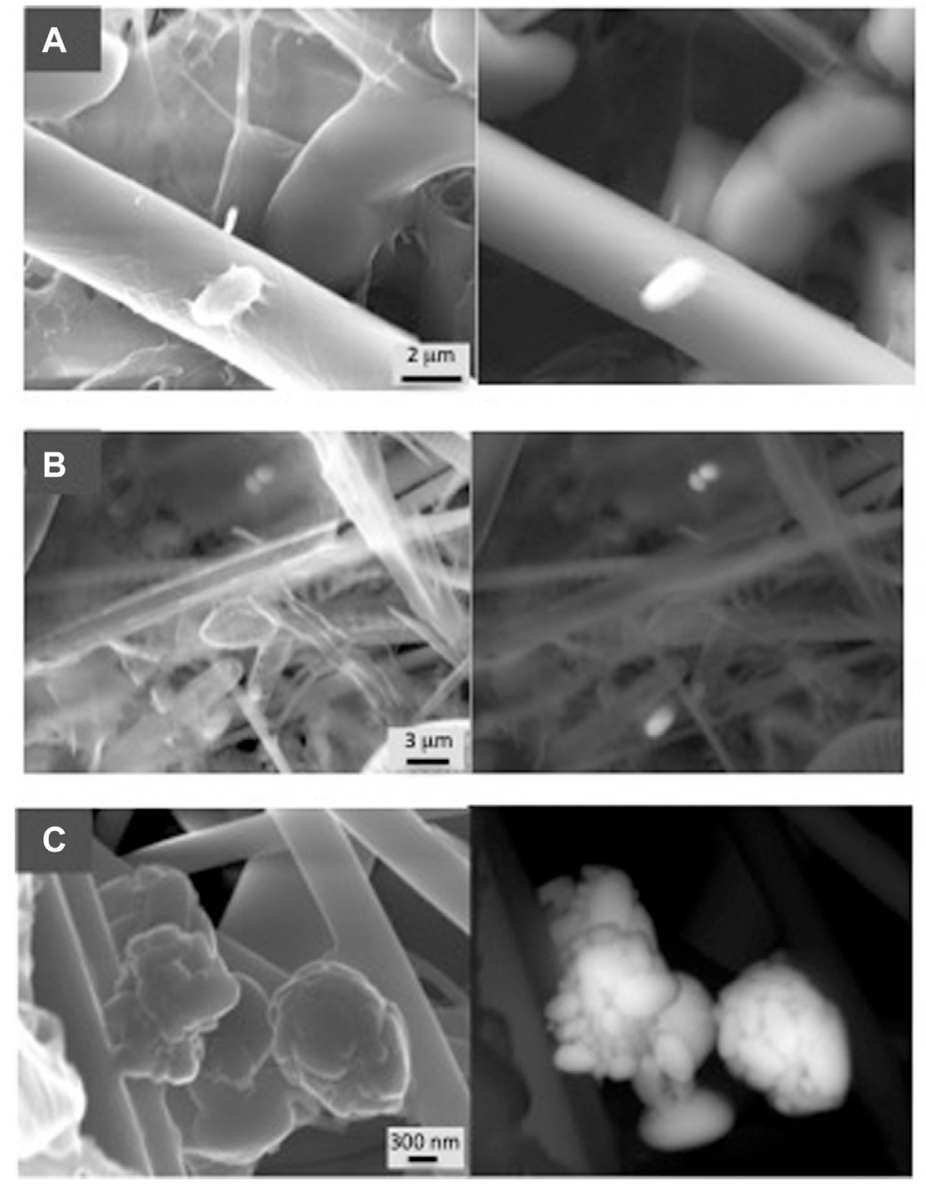

FIGURE 4 | SEM photographs showing representative examples of barite from the Indian sector of the Southern Ocean. Samples are indicated in Table 1. Both secondary electron and in backscattered electron (BSE) mode at 30 kV are shown in each sample. (A) GCM 199 (20 m), (B) GCM 197 (125 m), (C) GCM 193 (500 m). (D) and (E) GCM 194 (300 m) show a detail of the different size of barite grains formed within organic aggregates.

observations confirm the abundance of barite throughout this water column including the deepest sample at $1,000 \mathrm{~m}$ water depth (Figure 3G) and demonstrate that barite is particularly abundant in the intermediate mesopelagic zone (Figures 3E,F; sample GCM 125, $500 \mathrm{~m}$ ). In the Indian sector of the Southern Ocean, a profile down to $800 \mathrm{~m}$ also shows higher barite abundance at depths corresponding to the upper mesopelagic zone (Figure 7). Crystals of different sizes are observed (Figure 4) as well as barite in organic aggregates (Figures 4D,E) at all depths. In the Antarctic sector of the South Pacific Ocean, barite shows similar morphologies and organic association as at the other sites (Figure 5). The particulate barite abundance at this station is slightly lower than at the studied station in the South Atlantic sector (Figure 7).

Electron microscopy observations demonstrate that morphology and composition of the barite particles are similar at all the studied ocean sectors and across depth in each station. The composition of the analyzed barite grains is similar to that previously reported in Martinez Ruiz et al. (2019), hence the EDX spectra are not shown in this work. EDX analyses show the expected barite composition, and in some cases, some barite grains also contain appreciable amounts of $\mathrm{Sr}$ and $\mathrm{P}$. Although some variability among sites and depths in the $\mathrm{P}$ and $\mathrm{Sr}$ content is seen, a clear quantitative pattern of vertical or spatial variability in the content of $\mathrm{P}$ and $\mathrm{Sr}$ cannot be established with the EDX available data. However, qualitatively, at the South Atlantic and South Indian ocean stations, the number of barite grains enriched in $\mathrm{Sr}$ and $\mathrm{P}$ generally decreased with depth, suggesting that barite grains are more enriched in these elements at shallow depths. Acantharia shells have also been observed at the shallow depths in several stations (South Atlantic and South Indian oceans and East Pacific). It is important to note that the large Si peaks in EDX analyses from the quartz filter substrate overlap with the Sr L alfa (1.806 keV) peak, which may mask Sr when it is not in high enough abundance. However, at high concentrations $\mathrm{Sr}$ is easily detectable by the $\mathrm{Sr} \mathrm{K}$ alfa 1 $(14.165 \mathrm{keV})$ peak, and this has been carefully checked in SEM and HRTEM EDX spectra. As reported by Martinez Ruiz et al. (2019), Sr is clearly present in some of the analyzed barite grains but in other cases it is not detectable likely because of relatively low concentrations resulting in peaks 

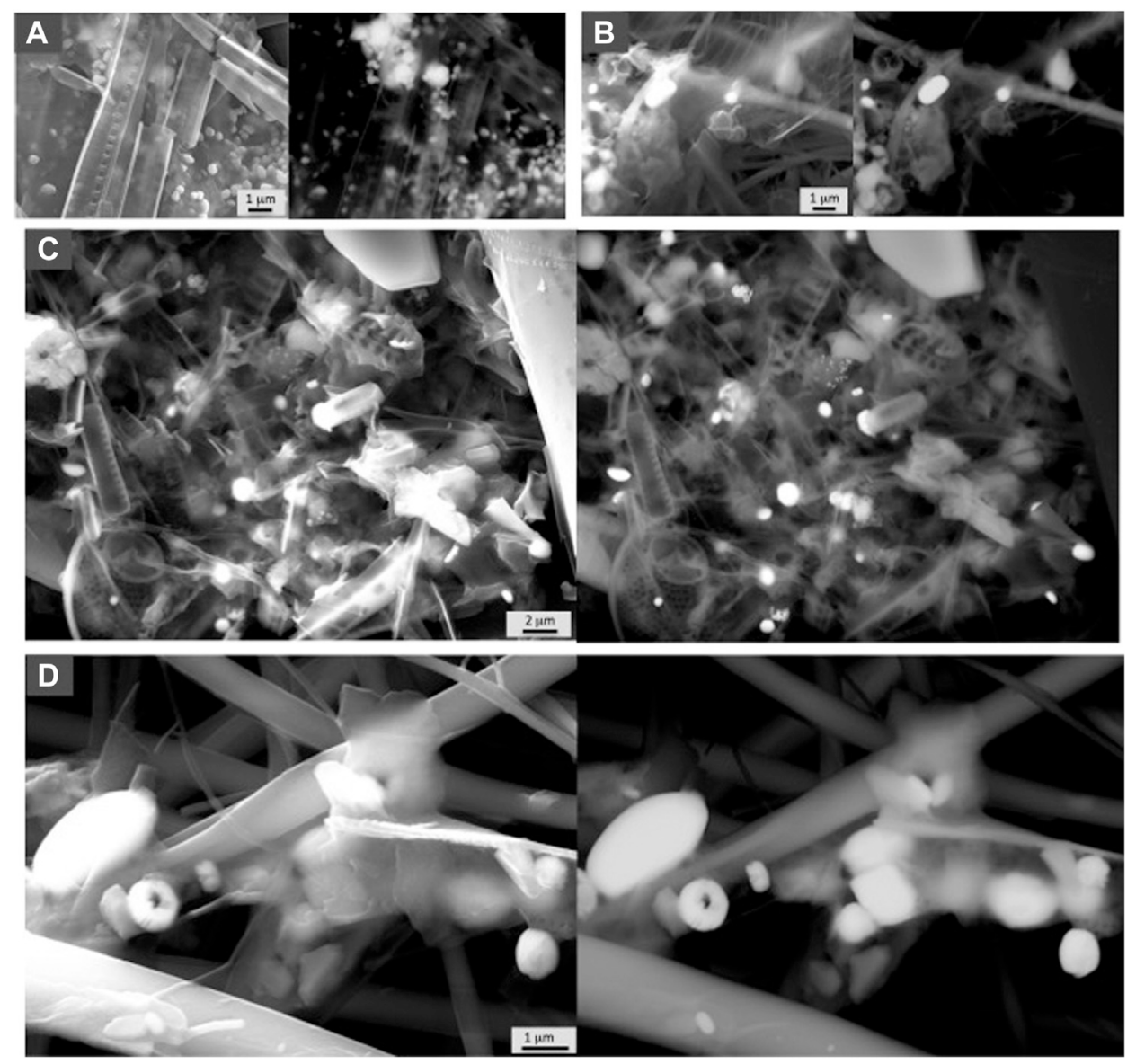

FIGURE 5 | SEM photographs showing representative examples of barite from the Southern Ocean edge Ross Sea sector. Samples are indicated in Table 1. Both secondary electron and in backscattered electron (BSE) mode at 30 kV are shown in each sample. (A) NBP 1017 (100 m), (B) NBP 1018 (150 m), (C) NBP 1019 (250 m) and (D) NBP 1021 (600 m). In all analyzed filter samples barite is particularly abundant.

obscured by the EDX Si spectra. HRTEM analyses also allow for Sr detection and indeed it is observed in many of the analyzed particles as shown in Figure 6. EDX maps also show that $\mathrm{Sr}$ content is variable at the nanometer scale and may vary even within the same particle (Martinez Ruiz et al., 2019).

Composition and crystallographic characteristics have been obtained by HRTEM. Representative examples are included in Figure 6. The analyses of organic aggregates indicate that barite crystallization starts with nanometer-sized amorphous precursors either P-rich (Martinez Ruiz et al., 2019) or with a barite-like composition and that the composition is variable even at this nano scale (Figures 6A-F). The amorphous nature of some of these particles is supported by SAED images and HRTEM diffraction data (Figure 6A). These analyses show crystals in which d-spaces corresponding to barite are clearly recognized (Figure 6G) as well as particles without a clear crystalline organization. High Angle Annular Dark Field (HAADF) STEM images and corresponding EDX map also demonstrate the high concentration of $\mathrm{P}$ and $\mathrm{Sr}$ in some of the barite grains (Figures 6C-E).
Particulate organic carbon (POC) and particulate $\mathrm{Ba}(\mathrm{pBa})$ profiles from the South Atlantic (Great Calcite Belt) Station 117 and the South Pacific Ocean (Antarctic sector) are shown in Figure 7. POC profiles are similar at both sites and show the typical POC profile with export out of the euphotic zone. At the Great Calcite Belt, Rosengard et al. (2015) argued that in this ocean region diatom-rich communities produce large and labile POC aggregates, which result in intense mineralization in the mesopelagic zone. The $\mathrm{pBa}$ profiles also support a significant increase in barite abundance at about $300 \mathrm{~m}$, decreasing above and below that depth. At the Antarctic sector, the pBa profile show barite down to the deepest sample $(600 \mathrm{~m})$ analyzed at this station. Samples recovered from the top $1,000 \mathrm{~m}$ at low latitude sub/tropical locations exhibit undersaturation $\left(\Omega_{\text {barite }}<\right.$ 1) in the epipelagic and upper mesopelagic zones (e.g., east Pacific, southeast Atlantic). In contrast, water samples from the high-latitude Southern Ocean are generally close to saturation $\left(\Omega_{\text {barite }}=1\right)$ or even slightly supersaturated $\left(\Omega_{\text {barite }}>1\right)$, consistent with previous studies (e.g., Monnin et al., 1999; Rushdi et al., 2000). 

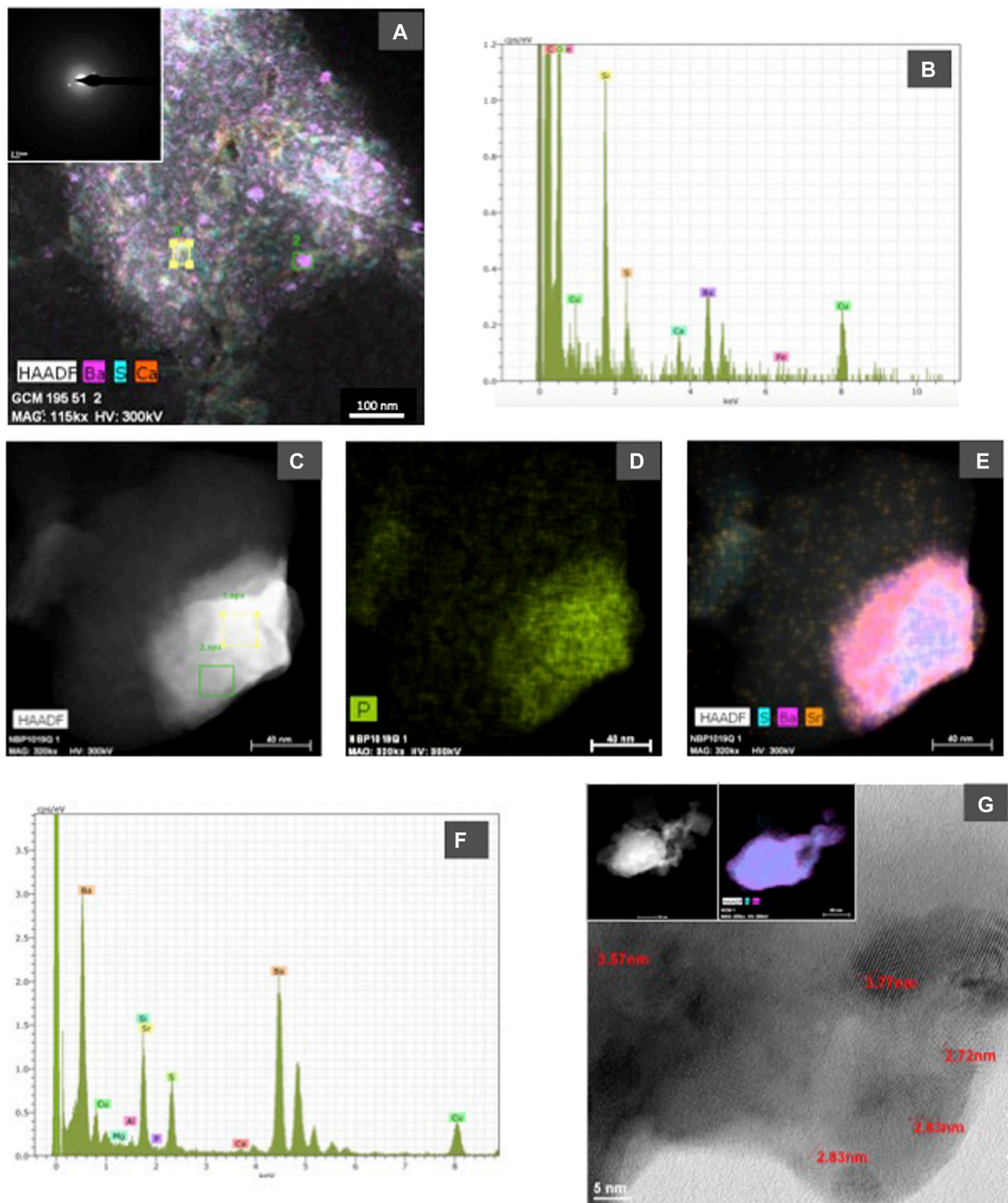

FIGURE 6 | (A) High Angle Annular Dark Field (HAADF) STEM image and corresponding EDX maps showing the distribution of S, Ba and Ca in an organic aggregate from sample GCM 195 (Indian sector of the Southern Ocean). In the upper left corner, a selected area electron diffraction (SAED) image obtained by HRTEM is included to show the poor crystallinity of the nanometer-sized particles with barite composition; (B) representative spectrum (indicated in the HAADF image as square 2) showing the barite composition of nanometer-sized particles; (C), (D), and (E) show HAADF-STEM images and corresponding EDX maps of P (D) and Sr, S, and $\mathrm{Ba}$ (E) in a barite particle from NBP 1019 sample; (F) representative EDX spectrum from the barite particle shown in photograph c. Analyzed area corresponds to square 2 in that photograph, the Sr peak shows its enrichment in this grain; (G) shows a lattice-fringe image from sample GCM 124 in which d-spaces characteristic of barite are indicated: $3.77 \AA$ (201), $3.57 \AA$ (002), $2.83 \AA$ (112), and 2.72 $\AA$ (020). In upper left side, a HAADF-STEM image and corresponding EDX maps (S and Ba) of the analyzed particle are included. 


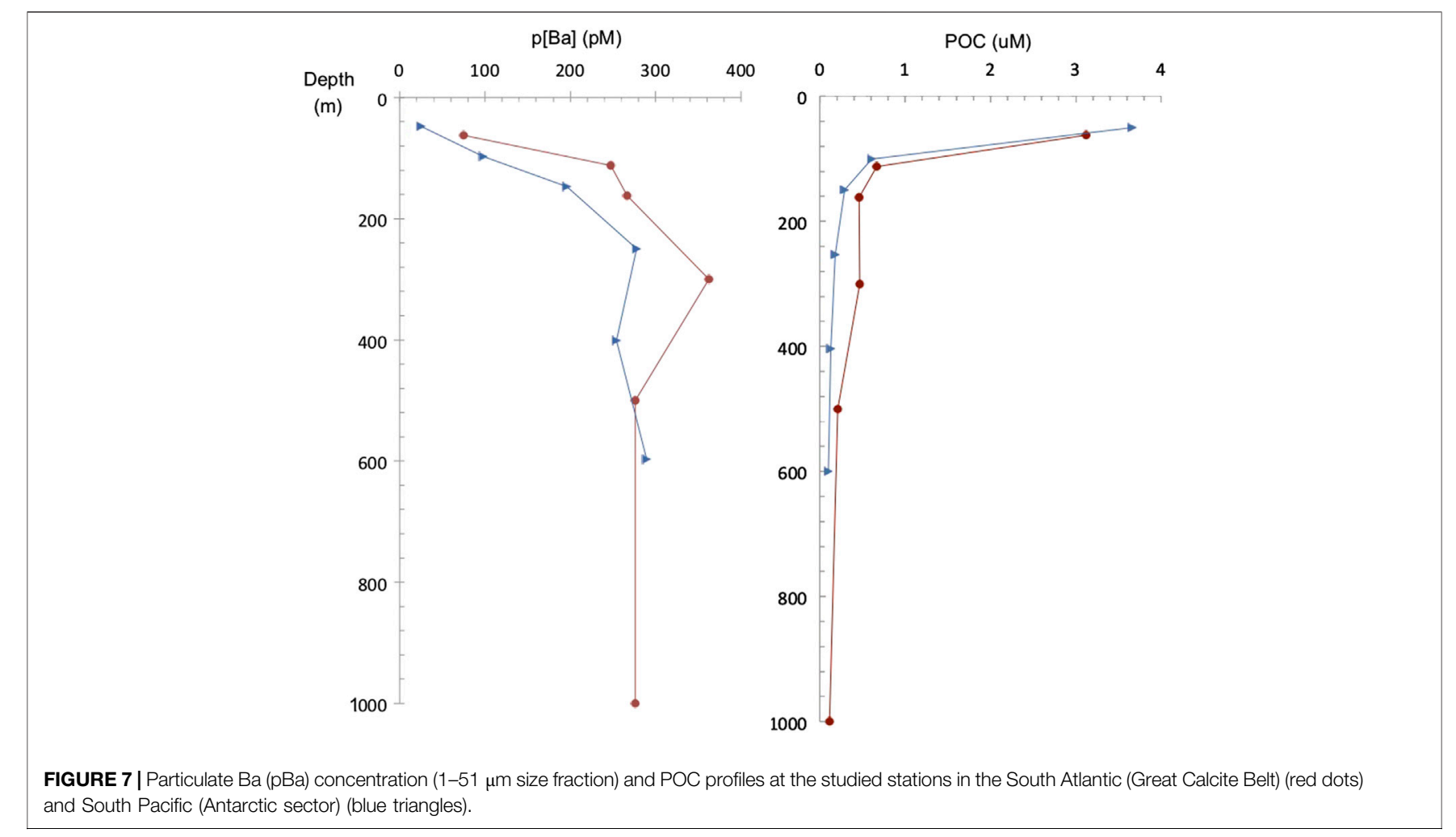

\section{DISCUSSION}

\section{Barite Distribution in the Open Ocean}

To date, a large body of work from multiple oceanographic expeditions and sampling location has provided ample datasets of $\mathrm{dBa}$ and non-lithogenic $\mathrm{pBa}$ distribution in the ocean water column. In general, the GEOTRACES-era datasets exhibit similar depth-dependent patterns in $\mathrm{pBa}$ to those shown here; however, this study also adds novel results regarding the mechanisms behind these distributions. It has been demonstrated that barite abundance shows significant spatial differences mostly related to productivity. Also, significant differences are recognized with depth in the water column since processes involved in precipitation are occurring at certain depths and the barite may dissolve deeper in the water column. Since $\mathrm{pBa}$ is closely correlated with the flux of organic carbon, it is enriched in the mesopelagic zone and typically shows a maximum abundance at intermediate depths (200-600 m) (e.g., Dehairs et al., 1980; Bishop, 1988; Dehairs et al., 1991; Dymond and Collier, 1996; Dehairs et al., 1997; Dehairs et al., 2008; Stenberg et al., 2008; Jacquet et al., 2011; Planchon et al., 2013; Lemaitre et al., 2018; Conte et al., 2019). Overall, vertical pBa profiles are similar to those of calculated oxygen consumption rates, which supports the link between organic matter degradation and barite formation (e.g., Dehairs et al., 1997). Importantly, pBa has been correlated with rates of microbial degradation of organic matter, which further support the link to oxygen consumption and carbon respiration. Barium isotopes also support barite formation at mesopelagic depths as demonstrated by enrichment in the isotopically-heavy $\mathrm{Ba}$ in seawater $\left({ }^{138} \mathrm{Ba}\right)$ and depletion of the lighter $\mathrm{Ba}\left({ }^{134} \mathrm{Ba}\right)$ due to the preferential incorporation of the lighter $\mathrm{Ba}$ isotopes in barite (Horner et al., 2015; Hsieh and Henderson, 2017; Bates et al., 2017; Bridgestock et al., 2018). Indeed a local maximum in $\delta^{138} \mathrm{Ba}$ at depths between 200 and $600 \mathrm{~m}$ in diverse ocean basins indicates that barite precipitation mostly occurs at these depths (Horner et al., 2015; Bates et al., 2017). Our pBa data from the two analyzed stations at the South Atlantic (Great Calcite Belt) and South Pacific (Antarctic sector) stations are also consistent with the idea of enhanced barite formation at this depth the mesopelagic zone. Profiles show higher $\mathrm{pBa}$ concentrations below $200 \mathrm{~m}$ and down to $600 \mathrm{~m}$ with a maximum in at about $200-400 \mathrm{~m}$. Though qualitative, SEM observations from all the analyzed stations similarly show higher barite abundance at these intermediate depths.

As discussed above, barite formation is linked to organic carbon mineralization and export production, however a notable spatial variability in the Ba:Corg ratio is found over ocean regions. For instance, sediment trap samples from the Western Atlantic have significantly lower $\mathrm{Ba} /$ Corg values than samples from the Pacific (e.g., Dymond and Collier, 1996). The causes for this spatial variability are still poorly understood. Differences in the Ba:Corg ratio have been related to the efficiency of mineralization of POC in the mesopelagic zone relative to the exported amount (e.g., Francois et al., 1995). Thus, using algorithms that relate $\mathrm{Ba}$ to carbon export may not be appropriate in regions of highly variable carbon flux. Moreover, barite formation may be affected by the rate at which particles sink, given that particles that are quickly removed from the water column by rapid sinking may reduce the likelihood for precipitation of particulate Ba phases (McManus et al., 2002). 
This has also added uncertainty to sedimentary Ba interpretations and paleoproductivity reconstructions, particularly to the use of $\mathrm{Ba}$ content as a quantitative proxy for reconstructing productivity. In general, the poor understanding of barite distribution in the water column stems from our limited knowledge of the processes leading to barite saturation. A better knowledge of such processes may improve our ability to assess changes in past productivity. Results from experimental work and from the analyses of $\mathrm{pBa}$ phases in the water column have recently shed light into potential mechanisms leading to saturation and precipitation of barite in microenvironments within sinking particulate matter in the mesopelagic zone (Martinez-Ruiz et al., 2018; Martinez-Ruiz et al., 2019). Collectively this work emphasizes the role of biofilms as $\mathrm{Ba}$ concentrating agents in a process that could be termed organomineralization. According to the Encyclopedia of Geobiology, organo-mineralization (Défarge, 2011) is a process of mineral formation mediated by organic matter (OM), independent of the living organisms which the $\mathrm{OM}$ derives from. The organic compounds may be excretion products or detached parts of living organisms, or relics and by-products of dead organisms that have been released into waters or incorporated into soils, sediments, or rocks. Our observations from suspended marine particulate matter agree with this process and further support previous findings. Our SEM and TEM observations at multiple stations also demonstrate that barite forms through a P-rich amorphous precursor phase, seen in the $\mathrm{pBa}$ composition, ranging from Ba-phosphate to Ba-sulfate consistent with previous studies from two Atlantic Ocean stations (MartinezRuiz et al., 2019). The present study adds further evidence in support of these findings. Moreover, although the $\Omega_{\text {barite }}$ (Table 2) in the epipelagic and upper mesopelagic zone at the newly studied ocean sectors differs from site to site, this does not seem to be a major control in barite precipitation as no relation between $\Omega_{\text {barite }}$ and $\mathrm{pBa}$ or barite abundance is evident. At all the studied stations, barite crystals show similar characteristics in terms of composition, size, distribution and association to organic material, prominently showing association with EPS-like morphologies, which further supports EPS production is a major factor in promoting barite formation (Figures 2-5) as well as organo-mineralization as a common process for barite formation throughout the ocean. Considering that the relation of $\mathrm{pBa}$ with export production depends on microbial processes related to organic matter degradation, barite formation is therefore linked to the suite of complex processes involved in the ocean biological carbon pump. Specifically, the fraction of primary production that leaves the upper ocean and is exported to depth, defined as export production is the fraction that "fuels" barite formation. Export production depends on diverse factors such as phytoplankton and zooplankton community structures, the formation of aggregates, sinking by ballasting, and bacterial mineralization rates (e.g., Francois et al., 2002; Cavan et al., 2015; Belcher et al., 2016; Le Moigne et al., 2016) and these factors change in space and time. For example, Henson et al. (2019) demonstrated that low primary production and high export efficiency regimes tend to occur when macro-zooplankton and bacterial abundances are low in the surface ocean. Thus, a large fraction of primary production is exported, likely as intact cells or phytoplankton-based aggregates. In contrast, when macrozooplankton and bacterial abundances in the surface ocean are high, the export efficiency decreases. These results support that the whole ecosystem structure, rather than just the phytoplankton community, play a major role in export efficiency (Dehairs et al., 1992). All these factors not only depend on seasonality but can also be very different at regional and global scales. Hence, appropriate knowledge of the processes involved in carbon export fluxes, the formation of organic aggregates, and particle sinking is required for assessing the relationship between productivity and $\mathrm{Ba}$ proxies, and proper interpretative care and caution are required for using $\mathrm{Ba}$ as a proxy for export production. As the relation between export production and barite largely depends on microbial processes and EPS production, temperature, oxygen abundance, and the type of organisms involved may impact this relationship. Although the reason for $\mathrm{Ba}$ accumulation in bacteria and EPS or in other living organisms is not yet well understood, it is known that bioaccumulation of $\mathrm{Ba}$ occurs throughout the ocean. The nucleation and crystallization of barite results in the formation of a highly stable mineral that is hard to dissolve under oxygenated conditions, consequently a relatively large fraction of the particulate barite that forms reaches the sediments (Paytan and Kastner, 1996). Barite accumulation in the sediment would therefore represent a record of the combination of diverse processes including export productivity, organic matter degradation, bacterial activity, and EPS production. This complexity should be considered when interpreting temporal and spatial variability in the Ba:Corg ratios and in barite accumulation in marine sediments.

\section{Role of Extracellular Polymeric Substances in Barite Precipitation}

Understanding the microbial processes leading to the formation of the mineral barite in the oceanic water column is crucial to determining the utility of Ba proxies for paleo-productivity and paleo-chemistry reconstructions. How and why $\mathrm{Ba}$ associates with organic matter in microenvironments and how the rates of organic matter decomposition affect barite production are key questions that link primary productivity or export productivity to barite abundance in marine sediments. The important role that EPS and microbial cells may play in nucleation and crystallization in the ocean is still far from being well understood at the molecular scale. Even though the EPS in the ocean have been widely investigated, their role in mediating mineral precipitation remains mostly unknown, in particular as it pertains to barite formation. In seawater, these secretions facilitate attachment to surfaces leading to the formation of biofilms, organic colloids, and larger aggregations of cells (marine snow). Though difficult to measure accurately, EPS represent a significant portion of the bioavailable carbon pool in the ocean. These substances occur in a range of molecular sizes, with diverse physical and chemical properties, and their composition includes polysaccharides, proteins, lipids, and nucleic acids (Decho and Gutierrez, 2017). In general, the attachment of microbes to surfaces, or 
to each other, provides higher environmental stability than being a free-living cell and may be favorable in the ocean (e.g., Flemming et al., 2016). The EPS matrix of biofilms provides a three-dimensional architecture framework (Decho, 2000) that is the building block of the aggregates suspended in the water column. These organic aggregates are known to be very rich in microbial communities with abundances up to two orders of magnitude higher than in the surrounding seawater environment (e.g., Alldredge et al., 1986; Herndl, 1988).

While both experimental work and observations in diverse natural environments have demonstrated that functional groups associated with EPS are able to bind different metal ions (e.g., Braissant et al., 2007; Tourney and Ngwenya, 2014), their precise role for the binding, trapping and concentrating metals in the open ocean has not been sufficiently investigated. For instance, in bioremediation, it has been demonstrated that the polyanionic nature of the EPS promotes the binding of heavy and toxic metal ions, and EPS use for detoxification of heavy metals is well known. Many examples have been described in the literature such as in the remediation of $\mathrm{Cd}, \mathrm{Cr}, \mathrm{Pb}, \mathrm{Ni}, \mathrm{Cu}, \mathrm{Al}$, and $\mathrm{U}$ (e.g., Beech and Cheung, 1995; Iyer et al., 2005; Bhaskar and Bhosle, 2006; Gerber et al., 2018). However, as many of these studies had commercial purposes, very few have addressed the ecological implications of marine EPS in metal biogeochemical cycles. Loaec et al. $(1997,1998)$ reported the heavy metal-binding capacity of EPS produced by hydrothermal vent bacteria and suggested that this could represent a survival strategy for the bacteria by reducing their exposure to toxic metals released from the hydrothermal vents. Major elements such as $\mathrm{Na}, \mathrm{Mg}, \mathrm{Ca}, \mathrm{K}$, $\mathrm{Sr}$, and $\mathrm{Si}$, have also been shown to be adsorbed by marine bacterial EPS (Gutierrez et al., 2008). Likewise, Fe uptake by EPS in eukaryotic phytoplankton has been investigated (Hassler et al., 2011; Gutierrez et al., 2012), and binding of Th to carboxylate, phosphate and sulfate groups in marine EPS has also been shown (Alvarado Quiroz et al., 2006). Nevertheless, the ecological implications of these binding processes are not well understood, and $\mathrm{Ba}$ has not been investigated yet in this regard. Thus, our data open an unexplored field and support the crucial role that EPS play not only for Ba bioaccumulation but also for mineral precipitation in the ocean, with important implications for paleo-oceanographic reconstructions. Although further investigations are required to elucidate precise nucleation and crystal growth processes, the available data strongly support that biofilm matrix is crucial for metal precipitation in the ocean. In this dynamic environment, with abundant microbial cells, polysaccharides and water, together with excreted cellular products (e.g., Sutherland, 2001), functional groups including sulfate and phosphate would contribute to the overall negative charge of the EPS, and these functional groups would interact with metals promoting precipitation.

\section{The Microbial Pump and Future Perspectives}

The use of barite as a proxy to gain insights into past microbial processes is a promising tool in paleoceanographic research. It is broadly known that microbial communities play a major role in biogeochemical cycles since they play a role both at the base of the oceanic food web and as decomposers (e.g., Falkowski et al., 2008; Robidart et al., 2019). Further knowledge of microbial productivity and structure of communities is required for predicting future marine ecosystem functions, and the impact of increasing environmental effects on ocean ecosystems. This is challenging at present because biogeochemical processes and microbial communities are very complex, but it is far more complex for the past because a record of microbial processes is not usually well preserved in marine sediments beyond the preservation of biomarkers and some minerals that form through direct or indirect association with microorganisms. Accordingly, although barite accumulation rates are closely correlated with carbon export to the deep ocean (Carter et al., 2020 and references therein), the occurrence of barite may also reflect Ba utilization in the surface ocean through microbial processes, EPS production and organic matter mineralization. Except in sulfate reducing environments, barite is well preserved in marine sediments, thus the presence of pelagic barite particles is an indication of past bacterial respiration processes. In fact, barite has been proposed as a good proxy reflecting average mineralization processes (e.g., Cardinal et al., 2005), which are in turn a major control in the global carbon cycle and atmospheric carbon sequestration (e.g., Cavan et al., 2017). Our observations at diverse ocean sectors and depths showing formation within organic aggregates commonly rich in EPS, further support that mineralization due to microbial respiration is responsible for barite formation and consequently barite is a bioindicator for such processes.

The occurrence of barite in marine particles may have additional effects that have so far not been thoroughly investigated. For example, the potential role of barite particles within marine snow in the ballasting and mineralization controls of carbon sedimentation. It has been demonstrated that particulate minerals, for instance eolian dust, can be incorporated into organic aggregates and act as ballast enhancing the marine carbon export hence the significant increase in the sinking velocities of aggregates (Van der Jagt et al., 2018). Although biological processes affecting the fragmentation and mineralization of large particles are the most important factors determining the POC profiles (e.g., Lam and Bishop, 2007), barite is a highdensity mineral that could also affect export processes. Another important aspect that still requires further investigation is the distribution of barite at greater depths than the mesopelagic zone. To date most of the studies on barite distribution have focused on mesopelagic depths and little is known about distribution and potential precipitation or dissolution with depth since only very few data from deeper samples are available (Conte et al., 2019). Furthermore, in the bathypelagic ocean (depth $>1,000 \mathrm{~m}$ ), Archaea and Viruses are particularly important in the microbial loop, but they remain largely unexplored in deep waters, and interactions between microbes and minerals beyond bacterial precipitation is almost unknown, except some recent work on the role of viruses in carbonate precipitation (e.g., Lan et al., 2020; White III et al., 2020). 


\section{CONCLUSIONS}

Comparisons of suspended marine particulate matter obtained from diverse ocean sectors indicate barite formation at intermediate depths $(200-600 \mathrm{~m})$ in the mesopelagic zone independent of barite saturation state. The formation of barite within organic aggregates in close association with EPS is a common process recognized in all the studied regions. Our results further confirm that microbial processes are mediating barite precipitation (organo-mineralization) within such aggregates as previously supported by experimental work showing that $\mathrm{Ba}$ binds to phosphate groups on cell surfaces and EPS in bacterial biofilms. Mineralogical and crystallographic characteristics of suspended barite particles in the ocean support the same crystallization path, from an amorphous P-rich phase to mineral barite. EPS play a crucial role in locally concentrating $\mathrm{Ba}$ and providing nucleation sites leading to saturation. The binding capacity of the functional groups associated with EPS, including phosphate groups, has been widely demonstrated in experimental conditions and diverse natural environments, and the interactions between $\mathrm{Ba}$ and the EPS is similarly occurring in the ocean leading to barite precipitation. The distribution of particulate $\mathrm{Ba}$ and $\mathrm{Ba}$ isotopes in the water column are consistent with this precipitation mechanism. Many processes are involved in barite precipitation including primary production, export production, organic matter degradation, bacterial respiration, EPS formation, aggregation and sinking, and all should be further investigated and taken into account when interpreting temporal and spatial variability in the Ba:Corg ratios and barite accumulation in sediments. In addition, EPS production by organisms other than bacteria, such as phytoplankton, may also play an important role in barite production. However, the ecological implications of these processes and interactions between diverse organisms have been poorly investigated. The strong link between organomineralization of pelagic barite and microbial processes could be used to gain insights into past microbial processes and the functioning of the microbial pump. This is of importance for reconstructing mineralization and microbial respiration, and their link to export production, which are key processes in the global carbon cycle and the ocean carbon sink.

\section{REFERENCES}

Abella-Gutiérrez, J., and Herguera, J. C. (2016). Sensitivity of carbon paleoproductivity in the Southern California current system on different time scales for the last $2 \mathrm{ka}$. Paleoceanogr. Paleoclimatol. 31, 953-970. doi:10.1002/2015PA002872

Alldredge, A. L., Cole, J. J., and Caron, D. A. (1986). Production of heterotrophic bacteria inhabiting macroscopic organic aggregates (marine snow) from surface waters. Limnol. Oceanogr. 31, 68-78. doi:10.4319/lo. 1986.31.1.0068

Alvarado Quiroz, N. G., Hung, C.-C., and Santschi, P. H. (2006). Binding of thorium(IV) to carboxylate, phosphate and sulfate functional groups from marine exopolymeric substances (EPS). Mar. Chem. 100, 337-353. doi:10.1016/ j.marchem.2005.10.023

Balch, W. M., Bates, N. R., Lam, P. J., Twining, B. S., Rosengard, S. Z., Bowler, B. C., et al. (2016). Factors regulating the great calcite belt in the Southern Ocean and

\section{DATA AVAILABILITY STATEMENT}

The raw data supporting the conclusions of this article will be made available by the authors, without undue reservation.

\section{AUTHOR CONTRIBUTIONS}

All authors listed have made a substantial contribution to the work and approved it for publication. FM conceived and led this project and has written the manuscript with an active contribution by discussing the results and writing from AP, $\mathrm{MK}$, and MG. MG and FJ also contributed to perform related culture experiments and to discuss microbiological aspects. PL provided the studied filter samples and corresponding information, and $\mathrm{TH}$ led the $\mathrm{pBa}$ analyses, and both contributed to the discussion. MA contributed TEM analytical data and corresponding discussion.

\section{FUNDING}

This study was supported by the European Regional Development Fund (ERDF) co-financed grants CGL201792600-EXP and PID2019-104624RB-I00 (Agencia Estatal de Investigación, Ministerio de Ciencia e Innovación, Spain), Research Groups RNM-179 and BIO 103, and Excellence Projects P18-RT-3804 and P18-RT-4074 (Junta de Andalucía), Unidad Cientifica de Excelencia UCE-PP2016-05 (University of Granada) and grant OCE-1443577.

\section{ACKNOWLEDGMENTS}

We thank the Center for Scientific Instrumentation (CIC, University of Granada) for electron microscopy analytical facilities, all the cruises supporting the sample collection, and laboratory assistance from C. W. Kinsley and H. V. Pryer for $\mathrm{pBa}$ analyses. We greatly acknowledge Frank Dehairs and Christophe Monnin whose constructive comments and suggestions helped improve and clarify this manuscript.

its biogeochemical significance. Global Biogeochem. Cycles. 30, 1124-1144. doi:10.1002/2016GB005414

Bates, S. L., Hendry, K. R., Pryer, H. V., Kinsley, C. W., Pyle, K. M., Woodward, E. M. S., et al. (2017). Barium isotopes reveal role of ocean circulation on barium cycling in the Atlantic. Geochem. Cosmochim. Acta. 204, 286-299. doi:10.1016/ j.gca.2017.01.043

Beech, I. B., and Cheung, C. W. S. (1995). Interactions of exopolymers produced by sulphate-reducing bacteria with metal ions. Int. Biodeterior. Biodegrad. 35, 59-72. doi:10.1016/0964-8305(95)00082-G

Belcher, A., Iversen, M., Giering, S., Riou, V., Henson, S. A., Berline, L., et al. (2016). Depth-resolved particle-associated microbial respiration in the northeast Atlantic. Biogeosciences. 13 (17), 4927-4943. doi:10.5194/bg-134927-2016

Bernstein, R. E., Byrne, R. H., Betzer, P. R., and Greco, A. M. (1992). Morphologies and transformations of celestite in seawater: the role of acantharians in strontium and barium geochemistry. Geochem. Cosmochim. Acta. 56, 3273-3279. doi:10.1016/0016-7037(92)90304-2 
Bernstein, R. E., Byrne, R. H., and Schijf, J. (1998). Acantharians: a missing link in the oceanic biogeochemistry of barium. Deep Sea Res. Oceanogr. Res. Pap. 45, 491-505. doi:10.1016/S0967-0637(97)00095-2

Bhaskar, P. V., and Bhosle, N. B. (2006). Bacterial extracellular polymeric substance (EPS): a carrier of heavy metals in the marine food-chain. Environ. Int. 32, 191-198. doi:10.1016/j.envint.2005.08.010

Bishop, J. K. B. (1988). The barite-opal-organic carbon association in oceanic particulate matter. Nature. 332, 341. doi:10.1038/332341a0

Bishop, J. K. B., Lam, P. J., and Wood, T. J. (2012). Getting good particles: accurate sampling of particles by large volume in-situ filtration. Limnol Oceanogr. Methods. 10, 681-710. doi:10.4319/lom.2012.10.681

Bishop, J. K. B., Schupack, D., Sherrell, R. M., and Conte, M. (1985). "A multipleunit large-volume in situ filtration system for sampling oceanic particulate matter in mesoscale environments," in Mapping strategies in chemical oceanography, Advances in chemistry. Washington, DC: American Chemical Society, Vol. 9, 155-175.

Bishop, J. K. B., and Wood, T. J. (2008). Particulate matter chemistry and dynamics in the twilight zone at VERTIGO ALOHA and K2 sites. Deep Sea Res. Oceanogr. Res. Pap. 55, 1684-1706. doi:10.1016/j.dsr.2008.07.012

Braissant, O., Decho, A. W., Dupraz, C., Glunk, C., Przekop, K. M., and Visscher, P. T. (2007). Exopolymeric substances of sulfate-reducing bacteria: interactions with calcium at alkaline $\mathrm{pH}$ and implication for formation of carbonate minerals. Geobiology. 5, 401-411. doi:10.1111/j.1472-4669.2007. 00117.x

Bridgestock, L., Hsieh, Y.-T., Porcelli, D., Homoky, W. B., Bryan, A., and Henderson, G. M. (2018). Controls on the barium isotope compositions of marine sediments. Earth Planet Sci. Lett. 481, 101-110. doi:10.1016/j.epsl.2017. 10.019

Brzezinski, M. A., and Washburn, L. (2011). Phytoplankton primary productivity in the santa barbara channel: effects of wind-driven upwelling and mesoscale eddies. J. Geophys. Res. 116, C12013. doi:10.1029/2011JC007397

Cardinal, D., Savoye, N., Trull, T. W., André, L., Kopczynska, E. E., and Dehairs, F. (2005). Variations of carbon remineralisation in the Southern Ocean illustrated by the Baxs proxy. Deep Sea Res. Oceanogr. Res. Pap. 52, 355-370. doi:10.1016/j. dsr.2004.10.002

Carter, S. C., Paytan, A., and Griffith, E. M. (2020). Toward an improved understanding of the marine barium cycle and the application of marine barite as a paleoproductivity proxy. Minerals. 10, 421. doi:10.3390/ $\min 10050421$

Cavan, E. L., Le Moigne, F. A. C., Poulton, A. J., Tarling, G. A., Ward, P., Daniels, C. J., et al. (2015). Attenuation of particulate organic carbon flux in the Scotia Sea, Southern Ocean, is controlled by zooplankton fecal pellets. Geophys. Res. Lett. 42, 821-830. doi:10.1002/2014GL062744

Cavan, E. L., Trimmer, M., Shelley, F., and Sanders, R. (2017). Remineralization of particulate organic carbon in an ocean oxygen minimum zone. Nat. Commun. 8, 14847. doi:10.1038/ncomms 14847

Chow, T. J., and Goldberg, E. D. (1960). On the marine geochemistry of barium. Geochem. Cosmochim. Acta. 20, 192-198. doi:10.1016/0016-7037(60)90073-95

Conte, M. H., Carter, A. M., Koweek, D. A., Huang, S., and Weber, J. C. (2019). The elemental composition of the deep particle flux in the Sargasso Sea. Chem. Geol. 511, 279-313. doi:10.1016/j. chemgeo.2018.11.001

Decho, A. W. (2000). "Exopolymer microdomains as a structuring agent for heterogeneity with microbial biofilms," in Microbial sediments. Editors R. E. Riding and S. M. Awramik (Berlin, Germany: Springer-Verlag Press), 9-15.

Decho, A. W., and Gutierrez, T. (2017). Microbial extracellular polymeric substances (EPSs) in Ocean systems. Front. Microbiol. 8, 922. doi:10.3389/ fmicb.2017.00922

Défarge, C. (2011). "Organomineralization," in Encyclopedia of Geobiology. Editors J. Reitner and V. Thiel (Dordrecht, Netherlands: Springer).

Dehairs, F., Baeyens, W., and Goeyens, L. (1992). Accumulation of suspended barite at mesopelagic depths and export production in the Southern Ocean. Science. 258, 1332-1335. doi:10.1126/science.258.5086.1332

Dehairs, F., Chesselet, R., and Jedwab, J. (1980). Discrete suspended particles of barite and the barium cycle in the open ocean. Earth Planet Sci. Lett. 49, 528-550. doi:10.1016/0012-821X(80)90094-1

Dehairs, F., Jacquet, S., Savoye, N., Van Mooy, B. A. S., Buesseler, K. O., Bishop, J. K. B., et al. (2008). Barium in twilight zone suspended matter as a potential proxy for particulate organic carbon remineralization: results for the North Pacific. Deep Sea Res. Part II Top. Stud. Oceanogr. 55, 1673-1683. doi:10.1016/j. dsr2.2008.04.020

Dehairs, F., Shopova, D., Ober, S., Veth, C., and Goeyens, L. (1997). Particulate barium stocks and oxygen consumption in the Southern Ocean mesopelagic water column during spring and early summer: relationship with export production. Deep Sea Res. Part II Top. Stud. Oceanogr. 44, 497-516. doi:10. 1016/S0967-0645(96)00072-0

Dehairs, F., Stroobants, N., and Goeyens, L. (1991). Suspended barite as a tracer of biological activity in the Southern Ocean. Mar. Chem. 35, 399-410. doi:10.1016/ S0304-4203(09)90032-9

Dymond, J., and Collier, R. (1996). Particulate barium fluxes and their relationships to biological productivity. Deep Sea Res. Part II Top. Stud. Oceanogr. 43, 1283-1308. doi:10.1016/0967-0645(96)00011-2

Dymond, J., Suess, E., and Lyle, M. (1992). Barium in deep-sea sediment: a geochemical proxy for paleoproductivity. Paleoceanogr. Paleoclimatol. 7, 163-181. doi:10.1029/92PA00181

Eagle, M., Paytan, A., Arrigo, K. R., van Dijken, G., and Murray, R. W. (2003). A comparison between excess barium and barite as indicators of carbon export. Paleoceanogr. Paleoclimatol. 18, 1021. doi:10.1029/2002PA000793

Enyedi, N. T., Makk, J., Kótai, L., Berényi, B., Klébert, S., Sebestyén, Z., et al. (2020). Cave bacteria-induced amorphous calcium carbonate formation. Sci. Rep. 10, 8696. doi:10.1038/s41598-020-65667-w

Falkowski, P. G., Fenchel, T., and DeLong, E. F. (2008). The microbial engines that drive Earth's biogeochemical cycles. Science. 320, 1034-1039. doi:10.1126/ science. 1153213

Flemming, H.-C., Wingender, J., Szewzyk, U., Steinberg, P., Rice, S. A., and Kjelleberg, S. (2016). Biofilms: an emergent form of bacterial life. Nat. Rev. Microbiol. 14, 563-575. doi:10.1038/nrmicro.2016.94

François, R., Honjo, S., Krishfield, R., and Manganini, S. (2002). Factors controlling the flux of organic carbon to the bathypelagic zone of the ocean. Global Biogeochem. Cycles. 16 (4), 1087. doi:10.1029/2001GB001722

François, R., Honjo, S., Manganini, S. J., and Ravizza, G. E. (1995). Biogenic barium fluxes to the deep sea: implications for paleoproductivity reconstruction. Global Biogeochem. Cycles. 9, 289-303. doi:10.1029/95GB00021

Ganeshram, R. S., François, R., Commeau, J., and Brown-Leger, S. L. (2003). An experimental investigation of barite formation in seawater. Geochem. Cosmochim. Acta. 67, 2599-2605. doi:10.1016/S0016-7037(03)00164-9

Gerber, U., Hübner, R., Rossberg, A., Krawczyk-Bärsch, E., and Merroun, M. L. (2018). Metabolism-dependent bioaccumulation of uranium by Rhodosporidium toruloides isolated from the flooding water of a former uranium mine. PLoS One. 13, e0201903. doi:10.1371/journal.pone.0201903

Geyman, B. M., Ptacek, J. L., LaVigne, M., and Horner, T. J. (2019). Barium in deepsea bamboo corals: phase associations, barium stable isotopes, and prospects for paleoceanography. Earth Planet Sci. Lett. 525, 115751. doi:10.1016/j.epsl.2019. 115751

Gingele, F., and Dahmke, A. (1994). Discrete barite particles and barium as tracers of paleoproductivity in South Atlantic sediments. Paleoceanogr. Paleoclimatol. 9, 151-168. doi:10.1029/93PA02559

González-Muñoz, M. T., Fernández-Luque, B., Martínez-Ruiz, F., Ben Chekroun, K., Arias, J. M., Rodríguez-Gallego, M., et al. (2003). Precipitation of barite by Myxococcus xanthus: possible implications for the biogeochemical cycle of barium. Appl. Environ. Microbiol. 69, 5722-5725. doi:10.1128/AEM.69.9.57225725.2003

Gonzalez-Muñoz, M. T., Martinez-Ruiz, F., Morcillo, F., Martin-Ramos, J. D., and Paytan, A. (2012). Precipitation of barite by marine bacteria: a possible mechanism for marine barite formation. Geology. 40, 675. doi:10.1130/G33006.1

Griffith, E. M., and Paytan, A. (2012). Barite in the ocean - occurrence, geochemistry and palaeoceanographic applications. Sedimentology. 59, 1817-1835. doi:10.1111/j.1365-3091.2012.01327.x

Gutierrez, T., Biller, D. V., Shimmield, T., and Green, D. H. (2012). Metal binding properties of the EPS produced by Halomonas sp. TG39 and its potential in enhancing trace element bioavailability to eukaryotic phytoplankton. Biometals. 25, 1185-1194. doi:10.1007/s10534-012-9581-3

Gutierrez, T., Shimmield, T., Haidon, C., Black, K., and Green, D. H. (2008). Emulsifying and metal ion binding activity of a glycoprotein exopolymer produced by Pseudoalteromonas sp. strain TG12. Appl. Enivorn. Microbiol. 74, 4867-4876. doi:10.1128/AEM.00316-08 
Hassler, C. S., Schoemann, V., Nichols, C. M., Butler, E. C. V., and Boyd, P. W. (2011). Saccharides enhance iron bioavailability to Southern Ocean phytoplankton. Proc. Natl. Acad. Sci. U.S.A. 108, 1076-1081. doi:10.1073/ pnas. 1010963108

Hatta, M., Measures, C. I., Lam, P. J., Ohnemus, D. C., Auro, M. E., Grand, M. M., et al. (2017). The relative roles of modified circumpolar deep water and benthic sources in supplying iron to the recurrent phytoplankton blooms above Pennell and Mawson banks, Ross sea, Antarctica. J. Mar. Syst. 166, 61-72. doi:10.1016/j. jmarsys.2016.07.009

Henson, S., Le Moigne, F., and Giering, S. (2019). Drivers of carbon export efficiency in the global ocean. Global Biogeochem. Cycles. 33, 891-903. doi:10.1029/2018GB006158

Henson, S. A., Sanders, R., and Madsen, E. (2012). Global patterns in efficiency of particulate organic carbon export and transfer to the deep ocean. Global Biogeochem. Cycles. 26, a. doi:10.1029/2011GB004099

Hernandez-Sanchez, M. T., Mills, R. A., Planquette, H., Pancost, R. D., Hepburn, L., Salter, I., and FitzGeorge-Balfour, T. (2011). Quantifying export production in the Southern Ocean:implications for the $\mathrm{Ba}_{\mathrm{xs}}$ proxy. Paleoceanogr. Paleoclimatol. 26, PA4222. doi:10.1029/2010PA002111

Herndl, G. (1988). Ecology of amorphous aggregations (marine snow) in the Northern Adriatic Sea. II. Microbial density and activity in marine snow and its implication to overall pelagic processes. Mar. Ecol. Prog. Ser. 48, 265-275. doi:10.3354/meps048265

Horner, T. J., Kinsley, C. W., and Nielsen, S. G. (2015). Barium-isotopic fractionation in seawater mediated by barite cycling and oceanic circulation. Earth Planet Sci. Lett. 430, 511-522. doi:10.1016/j.epsl.2015.07.027

Hsieh, Y.-T., and Henderson, G. M. (2017). Barium stable isotopes in the global ocean: tracer of Ba inputs and utilization. Earth Planet Sci. Lett. 473, 269-278. doi:10.1016/j.epsl.2017.06.024

Iyer, A., Mody, K., and Jha, B. (2005). Biosorption of heavy metals by a marine bacterium. Mar. Pollut. Bull. 50, 340-343. doi:10.1016/j.marpolbul.2004.11.012

Jacquet, S. H. M., Dehairs, F., Dumont, I., Becquevort, S., Cavagna, A.-J., and Cardinal, D. (2011). Twilight zone organic carbon remineralization in the polar front zone and subantarctic zone south of tasmania. Deep Sea Res. Part II Top. Stud. Oceanogr. 58, 2222-2234. doi:10.1016/j.dsr2.2011.05.029

Jeandel, C., Dupré, B., Lebaron, G., Monnin, C., and Minster, J.-F. (1996). Longitudinal distributions of dissolved barium, silica and alkalinity in the western and southern Indian Ocean. Deep Sea Res. Oceanogr. Res. Pap. 43, 1-31. doi:10.1016/0967-0637(95)00098-4

Karl, D. M., and Church, M. J. (2017). Ecosystem structure and dynamics in the North pacific subtropical gyre: new views of an old ocean. Ecosystems. 20, 433-457. doi:10.1007/s10021-017-0117-0

Kester, D. R., Duedall, I. W., Connors, D. N., and Pytkowicz, R. M. (1967). Preparation of artificial Seawater. Limnol. Oceanogr. 12, 176-179. doi:10.4319/ lo.1967.12.1.0176

Ku, T.-L., and Lin, M.-C. (1976). ${ }^{226}$ Ra distribution in the antarctic ocean. Earth Planet Sci. Lett. 32, 236-248. doi:10.1016/0012-821X(76)90064-9

Lam, P. J., and Bishop, J. K. B. (2007). High biomass, low export regimes in the Southern Ocean. Deep Sea Res. Part II Top. Stud. Oceanogr. 54, 601-638. doi:10. 1016/j.dsr2.2007.01.013

Lan, Z., Zhang, S., Tucker, M., Li, Z., and Zhao, Z. (2020). Evidence for microbes in early Neoproterozoic stromatolites. Sediment. Geol. 398, 105589. doi:10.1016/j. sedgeo.2020.105589

Le Moigne, F. A. C., Henson, S. A., Cavan, E., Georges, C., Pabortsava, K., Achterberg, E. P., et al. (2016). What causes the inverse relationship between primary production and export efficiency in the Southern Ocean? Geophys. Res. Lett. 43, 4457-4466. doi:10.1002/2016GL068480

Lemaitre, N., Planquette, H., Planchon, F., Sarthou, G., Jacquet, S., García-Ibáñez, M. I., et al. (2018). Particulate barium tracing of significant mesopelagic carbon remineralisation in the North Atlantic. Biogeosciences. 15, 2289-2307. doi:10. 5194/bg-15-2289-2018

Letelier, R. M., Björkman, K. M., Church, M. J., Hamilton, D. S., Mahowald, N. M., Scanza, R. A., et al. (2019). Climate-driven oscillation of phosphorus and iron limitation in the North Pacific subtropical gyre. Proc. Natl. Acad. Sci. U.S.A. 116 12720-12728. doi:10.1073/pnas.1900789116

Loaëc, M., Olier, R., and Guezennec, J. (1997). Uptake of lead, cadmium and zinc by a novel bacterial exopolysaccharide. Water Res. 31, 1171-1179. doi:10.1016/ S0043-1354(96)00375-2
Loaëc, M., Olier, R., and Guezennec, J. (1998). Chelating properties of bacterial exopolysaccharides from deep-sea hydrothermal vents. Carbohydr. Polym. 35, 65-70. doi:10.1016/S0144-8617(97)00109-4

Ma, Z., Ravelo, A. C., Liu, Z., Zhou, L., and Paytan, A. (2015). Export production fluctuations in the eastern equatorial Pacific during the Pliocene-Pleistocene: reconstruction using barite accumulation rates. Paleoceanogr Paleoclimatol. 30, 1455. doi:10.1002/2015PA002860

Marsay, C. M., Sedwick, P. N., Dinniman, M. S., Barrett, P. M., Mack, S. L., and McGillicuddy, D. J. (2014). Estimating the benthic efflux of dissolved iron on the Ross Sea continental shelf. Geophys. Res. Lett. 41, 7576-7583. doi:10.1002/ $2014 \mathrm{gl} 061684$

Martinez-Ruiz, F., Jroundi, F., Paytan, A., Guerra-Tschuschke, I., Abad, M. M., and González-Muñoz, M. T. (2018). Barium bioaccumulation by bacterial biofilms and implications for Ba cycling and use of Ba proxies. Nat. Commun. 9, 1619. doi:10.1038/s41467-018-04069-z

Martinez-Ruiz, F., Paytan, A., Gonzalez-Muñoz, M. T., Jroundi, F., Abad, M. M., Lam, P. J., et al. (2019). Barite formation in the ocean: origin of amorphous and crystalline precipitates. Chem. Geol. 511, 441-451. doi:10.1016/j.chemgeo.2018. 09.011

McManus, J., Dymond, J., Dymond, J., Dunbar, R. B., and Collier, R. W. (2002). Particulate barium fluxes in the Ross Sea. Mar. Geol. 184, 1-15. doi:10.1016/ S0025-3227(01)00300-0

Measures, C., Hatta, M., and Grand, M. (2012). Bioactive trace metal distributions and biogeochemical controls in the Southern Ocean. Oceanography. 25, 122-133. doi:10.5670/oceanog.2012.85\#sthash.KE78XEDj.dpuf

Miot, J., Benzerara, K., Morin, G., Kappler, A., Bernard, S., Obst, M., et al. (2009). Iron biomineralization by anaerobic neutrophilic iron-oxidizing bacteria. Geochem. Cosmochim. Acta. 73 (3), 696-711. doi:10.1016/j.gca.2008.10.033

Monnin, C., Jeandel, C., Cattaldo, T., and Dehairs, F. (1999). The marine barite saturation state of the world's oceans. Mar. Chem. 65, 253-261. doi:10.1016/ S0304-4203(99)00016-X

Morcillo, F., González-Muñoz, M. T., Reitz, T., Romero-González, M. E., Arias, J. M., and Merroun, M. L. (2014). Biosorption and biomineralization of U(VI) by the marine bacterium Idiomarina loihiensis $\mathrm{MAH}_{1}$ : effect of background electrolyte and pH. PLoS One. 9, e91305. doi:10.1371/journal.pone.0091305

Nürnberg, C. C., Bohrmann, G., Schlüter, M., and Frank, M. (1997). Barium accumulation in the atlantic sector of the Southern Ocean: results from 190,000-year records. Paleoceanogr Paleoclimatol. 12, 594-603. doi:10.1029/ 97PA01130

Parkhurst, D. L., and Appelo, C. A. J. (2013). Description of input and examples for PHREEQC version 3-a computer program for speciation, batch-reaction, onedimensional transport, and inverse geochemical calculations. Reston, CA: United States Geological Survey, 6-A43, 497.

Paytan, A., and Griffith, E. M. (2007). Marine barite: recorder of variations in ocean export productivity. Deep Sea Res. Part II Top. Stud. Oceanogr. 54, 687-705. doi:10.1016/j.dsr2.2007.01.007

Paytan, A., and Kastner, M. (1996). Benthic Ba fluxes in the central Equatorial Pacific, implications for the oceanic Ba cycle. Earth Planet Sci. Lett. 142, 439-450. doi:10.1016/0012-821x(96)00120-3

Paytan, A., Kastner, M., and Chavez, F. P. (1996). Glacial to interglacial fluctuations in productivity in the equatorial pacific as indicated by marine barite. Science. 274, 1355-1357. doi:10.1126/science.274.5291.1355

Planchon, F., Cavagna, A.-J., Cardinal, D., André, L., and Dehairs, F. (2013). Late summer particulate organic carbon export and twilight zone remineralisation in the Atlantic sector of the Southern Ocean. Biogeosciences. 10, 803-820. doi:10. 5194/bg-10-803-2013

Rivadeneyra, M. A., Martín-Algarra, A., Sánchez-Román, M., Sánchez-Navas, A., and Martín-Ramos, J. D. (2010). Amorphous Ca-phosphate precursors for Cacarbonate biominerals mediated by Chromohalobacter marismortui. ISME J. 4, 922-932. doi:10.1038/ismej.2010.17

Robidart, J. C., Magasin, J. D., Shilova, I. N., Turk-Kubo, K. A., Wilson, S. T., Karl, D. M., et al. (2019). Effects of nutrient enrichment on surface microbial community gene expression in the oligotrophic North Pacific subtropical gyre. ISME J. 13, 374-387. doi:10.1038/s41396-018-0280-0

Rosengard, S. Z., Lam, P. J., Balch, W. M., Auro, M. E., Pike, S., Drapeau, D., and Bowler, B. (2015). Carbon export and transfer to depth across the Southern Ocean great calcite belt. Biogeosciences. 12, 3953-3971. doi:10.5194/bg-123953-2015 
Ruiz-Agudo, C., McDonogh, D., Avaro, J. T., Schuppa, D. J., and Gebauer, D. (2020). Capturing an amorphous $\mathrm{BaSO}_{4}$ intermediate precursor to barite. CrystEngComm. 22, 1310-1313. doi:10.1039/C9CE01555H

Rushdi, A. I., McManus, J., and Collier, R. W. (2000). Marine barite and celestite saturation in seawater. Mar. Chem. 69, 19-31. doi:10.1016/S0304-4203(99) 00089-4

Sánchez-Navas, A., and Martín-Algarra, A. (2001). Genesis of apatite in phosphate stromatolites. Eur. J. Mineral. 13 (2), 361-376. doi:10.1127/0935-1221/01/0013-0361

Sedwick, P. N., DiTullio, G. R., and Mackey, D. J. (1997). Regulation of algal blooms in Antarctic Shelf Waters by the release of iron from melting sea ice. Geophys. Res. Lett. 24, 2515-2518. doi:10.1029/2000jc000256

Sedwick, P. N., Marsay, C. M., Sohst, B. M., Aguilar-Islas, A. M., Lohan, M. C., Long, M. C., et al. (2011). Early season depletion of dissolved iron in the Ross Sea polynya: implications for iron dynamics on the Ant- arctic continental shelf. J. Geophys. Res. 116, C12019. doi:10.1029/2010JC006553

Smith, H. E. K., Poulton, A. J., Garley, R., Hopkins, J., Lubelczyk, L. C., Drapeau, D. T., et al. (2017). The influence of environmental variability on the biogeography of coccolithophores and diatoms in the great calcite belt. Biogeosciences. 14, 4905-4925. doi:10.5194/bg-14-4905-2017

Smith, W. O., Jr., Ainley, D. G., Arrigo, K. R., and Dinniman, M. S. (2014). The oceanography and ecology of the Ross Sea. Annu. Rev. Mar. Sci. 6, 469-487. doi:10.1146/annurev-marine-010213-135114

Sternberg, E., Jeandel, C., Robin, E., and Souhaut, M. (2008). Seasonal cycle of suspended barite in the Mediterranean Sea. Geochem. Cosmochim. Acta. 72, 4020-4034. doi:10.1016/j.gca.2008.05.043

Sutherland, I., (2001). The biofilm matrix - an immobilized but dynamic microbial environment. Trends Microbiol. 9, 222-227. doi:10.1016/S0966-842X(01) 02012-1

Sutton, T. T., Clark, M. R., Dunn, D. C., Halpin, P. N., Rogers, A. D., Guinotte, J., et al. (2017). A global biogeographic classification of the mesopelagic zone. Deep Sea Res. Oceanogr. Res. Pap. 126, 85-102. doi:10.1016/j.dsr.2017.05.006
Torres-Crespo, N., Martínez-Ruiz, F., González-Muñoz, M. T., Bedmar, E. J., De Lange, G. J., and Jroundi, F. (2015). Role of bacteria in marine barite precipitation: a case study using Mediterranean seawater. Sci. Total Environ. 512-513, 562-571. doi:10.1016/j.scitotenv.2015.01.044

Tourney, J., and Ngwenya, B. T. (2014). The role of bacterial extracellular polymeric substances in geomicrobiology. Chem. Geol. 386, 115-132. doi:10. 1016/j.chemgeo.2014.08.011

Van der Jagt, H., Friese, C., Stuut, J.-B. W., Fischer, G., and Iversen, M. H. (2018). The ballasting effect of Saharan dust deposition on aggregate dynamics and carbon export: aggregation, settling, and scavenging potential of marine snow. Limnol. Oceanogr. 63, 1386. doi:10.1002/lno.10779

Weiner, S., Sagi, I., and Addadi, L. (2005). Structural biology: choosing the crystallization path less traveled. Science. 309, 1027-1028. doi:10.1126/ science. 1114920

White, R. A., III, Visscher, P. T., and Burns, B. P. (Forthcoming, 2020). Between a rock and a soft place: the role of viruses in lithification of modern microbial mats. Trends Microbiol. doi:10.1016/j.tim.2020.06.004

Wolgemuth, K., and Broecker, W. S. (1970). Barium in sea water. Earth Planet Sci. Lett. 8, 372-378. doi:10.1016/0012-821X(70)90110-X

Conflict of Interest: The authors declare that the research was conducted in the absence of any commercial or financial relationships that could be construed as a potential conflict of interest.

Copyright (c) 2020 Martinez-Ruiz, Paytan, Gonzalez-Muñoz, Jroundi, Abad, Lam, Horner and Kastner. This is an open-access article distributed under the terms of the Creative Commons Attribution License (CC BY). The use, distribution or reproduction in other forums is permitted, provided the original author(s) and the copyright owner(s) are credited and that the original publication in this journal is cited, in accordance with accepted academic practice. No use, distribution or reproduction is permitted which does not comply with these terms. 